\title{
LOS INFORMES DE VISITA AD LIMINA DEL CARDENAL LORENZANA EN TOLEDO (1772-1800)
}

\author{
POR \\ ÁNGEL FERNÁNDEZ COLLAdo \\ Universidad deCastilla-La Mancha
}

\section{RESUMEN}

Análisis de las visitas ad limina del cardenal Lorenzana de los años 1776, $1780,1784,1788,1792$ y 1796 . Se realiza una síntesis de cada informe, que se incluyen como apéndice documental en su lengua de redacción original.

PALABRAS CLAVE: Toledo, siglo XVIII, visitas ad limina, Cardenal Lorenzana.

\begin{abstract}
Analysis of the visits ad limina of the cardinal Lorenzana during the years $1776,1780,1784,1788,1792$ and 1796. It is accomplished with a synthesis of each report, that are included as documental appendix in its original draft language.
\end{abstract}

KEY WORDS: Toledo, XVIII ${ }^{\text {th }}$ century, visits ad limina, Cardinal Lorenzana.

La visita ad limina $a^{1}$ es una práctica eclesial que realizan periódicamente todos los obispos del mundo desde hace varios siglos. Su realización integra tres actos o momentos que, avalados por una costumbre antiquísima observada por los prelados y regulada después canónicamente, van a ser constantes a lo largo de la historia:

1 A. LUCIDI, De visitatione sacrorum liminum. Instructio S. C. Concilii edita iussu S. M. Benedicti XIII, 3 v., Roma 1883. F. CAPELLO, De visitatione sacrorum liminum et dioeceseon, 2 v., Roma 1912. 
1. Visita a los sepulcros de los apóstoles Pedro y Pablo en Roma.

2. Visita al Papa, sucesor de Pedro.

3. Presentación de una Relación o Informe sobre el estado de la diócesis.

Esta práctica, realizada en algunas ocasiones personalmente por el Ordinario y en otras por medio de un procurador nombrado al efecto, expresa claramente la vivencia de una eclesiología de comunión: comunión eclesial, comunión de todos los obispos con la Sede de Pedro, y comunión mutua entre los obispos y el Papa.

El contacto personal del Papa con los obispos - un aspecto de los más importantes de su ministerio pontificio - encuentra su realización periódica en el acto de la visita ad limina. Esta visita ofrece a los obispos la oportunidad de llegar hasta Roma y allí venerar las tumbas de los príncipes de los Apóstoles, videre Petrum, encontrarse personalmente con el Papa, y celebrar a su nivel mas alto la comunión eclesial ${ }^{2}$. Y al Papa le permite intercambiar en nombre de Cristo el beso santo de la caridad y de la paz, manifestar visiblemente que es el Vicario de Cristo y, también, encontrarse personalmente con el obispo, estar juntos, hablar y compartir recíprocamente pensamientos, problemas y anhelos, reconocer su autoridad, ayudarlo, confirmarlo en el sentido evangélico de la palabra, y confortarlo en el ejercicio de su responsabilidad, para que vele sobre la grey en la que el Espíritu Santo le ha constituido Pastor.

Como sucesor de Pedro y pastor de todos los fieles, el Papa tiene la obligación de mirar por el bien la Iglesia universal y de todas las Iglesias particulares. Para realizar esta misión, necesita mantener comunicación con los fieles de todo el mundo, obviamente a través de sus pastores. Y esto lo logra, entre otros medios, por medio de sus viajes, hoy día tan frecuentes, con la relación epistolar, y con los encuentros motivados por las Visitas ad limina, los cuales tienen el aspecto inmediato y vivo del encuentro personal y de la entrega de un informe preparado cuidadosamente sobre la vida y la actividad de las iglesias particulares.

La visita personal al Santo Padre se ha transformado, a partir de Pablo VI y con Juan Pablo II, en una recepción colectiva de un grupo de obispos, agrupados por provincias eclesiásticas, por regiones o con situaciones pastorales similares. La evolución de los tiempos, la complejidad de los problemas y el carácter supradiocesano de algunas situaciones han recomendado el uso de esta práxis. El nuevo sistema, aunque disminuye la intimidad, ha dado un carácter colegial a la visita, muy en la línea del Concilio. Con todo, nunca se excluye una audiencia individual cuando hay asuntos importantes.

\footnotetext{
2 AAS 67 (1975) 674-676 (Decreto «Ad Romanam Ecclesiam»).
} 


\section{LA DIÓCESIS DE TOLEDO Y LOS INFORMES DE VISITA AL LIMINA.}

El conocimiento de la historia de una diócesis y del hacer pastoral de sus obispos tiene un importante punto de referencia en los informes sobre el estado de la diócesis presentados por los obispos en Roma, en el cumplimiento de la obligación periódica de visitar la Sede Apostólica y de dar cuenta del ejercicio de su ministerio. Estos informes, conservados hoy en el Archivo Secreto Vaticano, entre las series de las Sagradas Congregaciones del Concilio y del Consistorio, son un importante fondo documental cuya publicación ayudará a completar la radiografia de la diócesis y de sus arzobispos en un momento histórico o época determinada. Son ya muchas las diócesis que han iniciado la publicación y análisis de estos documentos históricos, aunque con criterios muy diferentes: Pamplona, Valencia y Segorbe, Oviedo, Avila, Urgel, Tarragona, Albarracín, Lérida, Cádiz, Orihuela, Zaragoza, Mondoñedo, León, Extremadura, Astorga, Cartagena, Almería, Burgos, Madrid, y Córdoba.

La obligación expresa del cumplimiento de la Visita ad limina y de la presentación de un informe sobre el estado de la diócesis surge con la publicación por parte del papa Sixto V de la Constitución Apostólica «Romanus Pontifex», en 1585.

El fondo documental existente en el Archivo Secreto Vaticano que conserva la información sobre las visitas ad limina de la diócesis de Toledo ${ }^{3}$ pone, hasta el momento, a disposición del investigador 31 Informes de visita al limina, correspondientes a 16 arzobispos. El primero está fechado en 1603 y el último en 1917.

Contamos, por tanto, con un abanico de mas de tres siglos, con treinta y un informes, relativamente homogéneos, y dieciséis arzobispos distintos, que nos permiten plasmar como en un gran lienzo la imagen de la diócesis de Toledo que surge de estas exposiciones, estimar las particularidades de algunos de los informes, descubrir las peculiaridades pastorales de algunos arzobispos y también contrastar un arzobispo con otro y una época con otra.

Ciertamente, los Informes son de valor desigual, unos están escritos en latín y otros en castellano, unos son breves y otros muy amplios, y en ellos abundan las repeticiones. No hay que olvidar que son informes de parte interesada. Es

3 Los Informes presentados por los arzobispos de Toledo se encuentran bajo estas signaturas archivísticas: Informes 1 al $10=A R C H I V O$ SECRETO VATICANO, Congregación del Concilio, Relationes Dioecesium, Toletana 805-A; Informes 11 al $22=A S V$, Congregación del Concilio, Relationes Dioecesium, Toletana 805-B; Informes 23 al $30=A S V$, Congregación del Concilio, Relationes Dioecesium, Toletana 805-C; e Informe $31=A S V$, Congregación del Consistorio, Relationes Dioecesium, Toletana 864. 
el Informe que da el propio obispo diocesano a Roma del estado de su diócesis y del ejercicio en ella de su ministerio pastoral.

Los informes repiten elementos descriptivos de escasa variación, como pueden ser los datos geográficos, la composición de los cabildos y colegiatas, el número de parroquias, de conventos y religiosos,... etc., aunque su comparación en diversas épocas es muy luminosa. Sin embargo, no profundizan o pasan muy rápidamente sobre otros aspectos de enjuiciamiento, dejando la información en niveles demasiado vagos o aéreos para el investigador. Con todo, en su conjunto, son muchísimos datos y elementos los que nos aportan: personas, instituciones, fundaciones, problemas, pleitos, defectos, atención a los más pobres, métodos pastorales, ... que abren horizontes al conocimiento y a la investigación histórica y que certifican noticias y hechos ya conocidos.

Los Informes presentados por los arzobispos de Toledo son los siguientes:

1.- Informe del año 1603. Arzobispo D. Bernardo Sandoval y Rojas.

2.- Informe del año 1615. Arzobispo D. Bernardo Sandoval y Rojas.

3.- Informe del año 1628. Cardenal D. Fernando de Austria.

4.- Informe del año 1645. Arzobispo D. Gaspar de Borja y Velasco.

5.- Informe del año 1650. Arzobispo D. Baltasar Moscoso y Sandoval.

6.- Informe del año 1660. Arzobispo D. Baltasar Moscoso y Sandoval.

7.- Informe del año 1672. Arzobispo D. Pascual de Aragón.

8.- Informe del año 1674. Arzobispo D. Pascual de Aragón.

9.- Informe del año 1685. Arzobispo D. Luis Manuel Fernández Portocarrero.

10.- Informe del año 1690. Arzobispo D. Luis Manuel Fernández Portocarrero.

11.- Informe del año 1695. Arzobispo D. Luis Manuel Fernández Portocarrero.

12.- Informe del año 1699. Arzobispo D. Luis Manuel Fernández Portocarrero.

13.- Informe del año 1705. Arzobispo D. Luis Manuel Fernández Portocarrero.

14.- Informe del año 1719. Arzobispo D. Francisco Valero y Losa.

15.- Informe del año 1723. Arzobispo D. Diego de Astorga y Céspedes.

16.- Informe del año 1727. Arzobispo D. Diego de Astorga y Céspedes.

17.- Informe del año 1731. Arzobispo D. Diego de Astorga y Céspedes.

18.- Informe del año 1769. Arzobispo D. Luis Fernández de Córdoba.

19.- Informe del año 1776. Arzobispo D. Francisco Antonio de Lorenzana.

20.- Informe del año 1780. Arzobispo D. Francisco Antonio de Lorenzana.

21.- Informe del año 1784. Arzobispo D. Francisco Antonio de Lorenzana.

22.- Informe del año 1788. Arzobispo D. Francisco Antonio de Lorenzana.

23.- Informe del año 1792. Arzobispo D. Francisco Antonio de Lorenzana.

24.- Informe del año 1796. Arzobispo D. Francisco Antonio de Lorenzana.

25.- Informe del año 1805. Arzobispo D. Luis $\mathrm{M}^{\mathrm{a}}$ de Borbón.

26.- Informe del año 1828. Arzobispo D. Pedro Inguanzo y Rivero. 
27.- Informe del año 1833. Arzobispo D. Pedro Inguanzo y Rivero.

28.- Informe del año 1878. Arzobispo D. Juan Ignacio Moreno y Maisonave.

29.- Informe del año 1890. Arzobispo D. Miguel Payá y Rico.

30.- Informe del año 1895. Arzobispo D. Antolín Monescillo y Viso.

31.- Informe del año 1917. Arzobispo D. Victoriano Guisasola y Menéndez.

El estudio y la documentación de todos estos Informes podrá estar dentro de unos meses en manos de los historiadores gracias al manuscrito que ya se encuentra preparado para su publicación en el Estudio Teológico San Ildefonso de Toledo. Por la personalidad del arzobispo y por su interés para un momento puntual de la historia de España y de la diócesis de Toledo ofrecemos ahora lel referido al cardenal Francisco Antonio de Lorenzana.

\section{DATOS BIOGRÁFICOS DEL CARDENAL LORENZANA}

Don Francisco Antonio de Lorenzana ${ }^{4}$ nació en León el 22 de septiembre de 1722. Estudió Gramática con los jesuitas de esta ciudad y Humanidades con los benedictinos de Espinareda. Cursó Teología y ambos Derechos en las Universidades de Valladolid y Salamanca, doctorándose «in utroque» en la de Salamanca. Aquí fue colegial y rector del colegio de San Salvador de Oviedo. En 1751, recibe la ordenación de presbítero y gana por oposición una canonjía en Sigüenza. En 1754 obtiene una canonjía de gracia en Toledo. El arzobispo don Luis Fernández de Córdoba lo nombró dignidad de abad de San Vicente y deán de la Catedral Primada. El 5 de junio de 1765 es nombrado obispo de Plasencia, aunque no llegó a tomar posesión de la diócesis, pues, el 14 de abril de 1766, fue nombrado arzobispo de México. Allí, como buen pastor preocu-

4 Luis SIERRA NAVA, El cardenal Lorenzana y la Ilustración, Fundación Universitaria Española, Madrid, 1975. Manuel GuTIÉRreZ GarCíA-BraZALES, Don Francisco Antonio de Lorenzana y Buitron (1772-1800), en «Los Primados de Toledo», Diputación Provincial, Toledo, 1993, 136-137; ID., El cardenal Lorenzana, preceptor de los hijos del infante don Luis, en Anales Toledanos, 18 (1984) 181230; ID., Francisco Antonio de Lorenzana, el cardenal ilustrado de Toledo, en III Simposio «Toledo Ilustrado", Centro Universitario, Toledo 1975, v. II, 5-26. Jesús FuENTES LÁZARO, Historia de la Real Casa de Caridad de Toledo..., en III Simposio «Toledo Ilustrado», Toledo: Centro Universitario, 1975, v. II, 67-88. Javier MALAGÓN-BARCELÓ, La obra escrita de Lorenzana como arzobispo de México (1766-1772), en III Simposio "Toledo Ilustrado»..., v. II, 27-66. Rafael OLAECHEA ABISTUR, El cardenal Lorenzana en el cónclave de Venecia, en III Simposio «Toledo Ilustrado»..., v. II, 89-184. Clemente PALENCIA FLORES, El cardenal Lorenzana, protector de la cultura en el siglo XVIII, Toledo 1946; ID., Labor social de un cardenal ilustrado en Toledo, en III Simposio «Toledo Ilustrado»..., v. II, 185-199. Miguel Ángel LÓPEZ NOMBELA, Lorenzana, vicario general en Toledo, en I Congreso de Historia de Castilla-La Mancha, Toledo 1988, v. VIII, 439-414. Gregorio SÁNCHEZ DONCEL, Visita pastoral del cardenal Lorenzana a la Plaza de Orán en Hispania Sacra 4 (1951) 391-440.

Instituciones eclesiásticas Hispania Sacra 54 (2002) 
pado por sus diocesanos a la vez que como hombre ilustrado, realiza la visita a la diócesis, predica a los sacerdotes y catequistas, escribe avisos y edictos referidos al adoctrinamiento de los indios, funda y organiza misiones, un hospital, un asilo y una casa de expósitos, reprime la esclavitud, tiene que ejecutar el decreto de expulsión de los jesuitas, publica un catecismo para párrocos, fomenta la composición de gramáticas indígenas, lleva a cabo proyectos urbanísticos, convoca y preside el IV Concilio Provincial, en 1771, y mecena el estudio de las antigüedades mejicanas, redactando personalmente la «Historia de la Nueva España».

El 27 de enero de 1772 es nombrado Arzobispo de Toledo. El rey le concede la Orden de Carlos III. El 30 de marzo de 1789 es nombrado cardenal y, en 1794, es designado Inquisidor General.

Durante su largo pontificado en la archidiócesis de Toledo, veintiocho años, la Ilustración encontró en él un genuino representante. Enriquece y abre al público la Biblioteca Arzobispal, se rodea de sabios y eruditos para llevar adelante la edición crítica de los Padres Toledanos, reedita el Breviario y el Misal Mozárabe, ampara y colabora en el proyecto paleográfico de F.J.S. Palomares y, con las respuestas de los curas a su «Interrogatorio» y la ayuda del geógrafo Tomás López, nos dejó una apreciada descripción etnográfica de los pueblos del arzobispado. Defiende la inmunidad de los territorios eclesiásticos. Levanta un nuevo edificio para la Universidad de Santa Catalina, construye un nuevo Hospital para Dementes en Toledo, instala Casas de Caridad en Toledo, Ciudad Real y Alcázar de San Juan, cuyos talleres y aulas ocupan a los sin trabajo y forman a la juventud, acoge y sustenta a los sacerdotes exiliados de Francia, visita el territorio de Orán, en 1786, inaugura paseos y fuentes públicas, ornamenta aún más la catedral, amplía el Palacio Arzobispal, e instruye con numerosas exhortaciones a los sacerdotes y al pueblo.

En 1797, Carlos IV, por indicación de Godoy, lo envió a Roma con la misión de llevar consuelo a Pío VI, muy afectado por el trato recibido por Napoleón; posteriormente lo nombró embajador. Participó en el cónclave de Venecia, en 1799, que eligió como papa a Pío VII y en el que Lorenzana era el candidato por España; socorrió con su dinero al colegio cardenalicio, renunció a la sede arzobispal de Toledo, el 21 de diciembre de 1800, y trabajó en la Congregación de Propaganda Fide y en la reforma de los estudios eclesiásticos. Murió en Roma, el 17 de abril de 1804, siendo enterrado en la Iglesia de la Santa Cruz de Jerusalén. En 1956 sus restos fueron trasladados a la catedral de México. 


\section{NOTICIAS DE LOS INFORMES Y DE LAS VISITAS}

El cardenal de Toledo, don Francisco Antonio de Lorenzana, presentó en Roma, en cumplimiento de las normas de la Visita ad Limina Apostolorum, un conjunto de seis Informes sobre el estado de la archidiócesis. Estos fueron los siguientes:

* Año 1776. Informe ${ }^{5}$ sobre el estado de la diócesis redactado en español, con 22 páginas, y fechado en Toledo el día 3 de junio de 1776. Al llegar a Roma hicieron una copia del mismo en italiano de 72 páginas. Actuó como Procurador don Francisco de Acedo y Torres, auditor en la Rota Romana por la Corona de Castilla y presbítero canónigo dignidad de Tesorero en la S.I. Catedral de Toledo. Visitó las Basílicas de San Pedro y San Pablo el 18 y 19 de julio de 1776. La respuesta desde Roma al contenido del Informe está fechada el 30 de mayo de 1777.

* Año 1780. Informe ${ }^{6}$ sobre el estado de la diócesis escrito en latín, con 45 páginas, y fechado en Toledo el día 20 de marzo de 1780. Actuó como Procurador don Francisco de Acedo y Torres, auditor en la Rota Romana por la Corona de Castilla y presbítero canónigo dignidad de Tesorero en la S.I. Catedral de Toledo. Visitó las Basílicas de San Pedro y San Pablo el 14 de mayo de 1780.

* Año 1784. Informe ${ }^{7}$ sobre el estado de la diócesis escrito en latín, con 4 páginas, y fechado en Toledo el día 5 de febrero de 1784. Actuó como Procurador don Francisco de Acedo y Torres, auditor en la Rota Romana por la Corona de Castilla y presbítero canónigo dignidad de Tesorero en la S.I. Catedral de Toledo. Visitó las Basílicas de San Pedro y San Pablo el 8 de marzo de 1784. La respuesta de Roma al contenido del Informe está fechada el 27 de junio de 1785 .

* Año 1788. Informe ${ }^{8}$ sobre el estado de la diócesis escrito en latín, con 9 páginas, y fechado en Toledo el día 30 de enero de 1788. Actuó como Procurador el abad dom Cayetano Ponti, residente en Roma. Visitó las Basílicas de San Pedro y San Pablo el 28 de febrero de 1788. La respuesta de Roma al contenido del Informe está fechada el 25 de marzo de 1788.

* Año 1792. Informe 9 sobre el estado de la diócesis escrito en latín, con 4 páginas, y fechado en Toledo el día 20 de enero de 1792. Actuó como Procu-

5 ASV, Congregación del Concilio, Relationes Dioecesium, Toletana 805-B.

6 ASV, Congregación del Concilio, Relationes Dioecesium, Toletana 805-B.

7 ASV, Congregación del Concilio, Relationes Dioecesium, Toletana 805-B.

8 ASV, Congregación del Concilio, Relationes Dioecesium, Toletana 805-B.

9 ASV, Congregación del Concilio, Relationes Dioecesium, Toletana 805-C.

Instituciones eclesiásticas Hispania Sacra 54 (2002) 
rador don Gregorio Alfonso Villagómez y Lorenzana, canónigo archidiácono de la S.I. Catedral de Toledo. Visitó las Basílicas de San Pedro y San Pablo el 12 de febrero de 1792.

* Año 1796. Informe ${ }^{10}$ sobre el estado de la diócesis escrito en latín, con 5 páginas, y fechado en Madrid el día 14 de febrero de 1796. Al llegar a Roma hicieron una copia del mismo en italiano. Actuó como Procurador el presbítero don Faustino Arévalo. Visitó las Basílicas de San Pedro y San Pablo el 21 de junio de 1796. La respuesta de Roma al contenido del Informe está fechada el 10 de febrero de 1797.

\section{ASPECTOS DESTACADOS DE LOS INFORMES}

\subsection{Informe del cardenal Lorenzana en $\mathbf{1 7 7 6}$}

El cardenal Francisco Antonio Lorenzana, siempre fiel cumplidor de sus obligaciones canónicas como pastor de la Archidiócesis toledana, a los cuatro años de tomar posesión de la Sede Primada, en 1776, envía a Roma el primero de los Informes sobre el estado de la diócesis. Es una visión panorámica de la diócesis, con datos ya conocidos y repetidos una y otra vez en los informes de algunos de los Arzobispos que le precedieron, y aspectos nuevos que van manifestando su estilo y la orientación de su pontificado. Sintetizamos ahora su contenido, destacando los aspectos mas sobresalientes y estructurándolos en diversos bloques temáticos.

\section{Ciudad de Toledo. Situación e importancia}

La Imperial ciudad de Toledo, situada en Castilla La Nueva, sobre una eminente cumbre circundada por el río Tajo, fue lugar de residencia de los reyes godos y, después de la expulsión de los moros, de los reyes de España. Sus armas son un Emperador sentado en su trono con espada desnuda en su mano derecha y un mundo en la izquierda. Es también la Sede Primada y en donde reside su Arzobispo. Su Iglesia tiene como armas la Descensión de Nuestra Señora imponiendo la casulla a San Ildefonso. Tiene Ayuntamiento y entre sus moradores hay un Intendente de Rentas y un Corregidor.

La ciudad tiene 25 Iglesias parroquiales, diecinueve latinas y seis mozárabes con sus derechos y privilegios. Son pobres por la disminución de sus rentas, a causa de la injuria de los tiempos y de la gracia del Excusado. La predi-

\footnotetext{
10 ASV, Congregación del Concilio, Relationes Dioecesium, Toletana 805-C.
} 
cación del Santo Evangelio y de la doctrina cristiana es frecuente en la ciudad y en las parroquias del Arzobispado por el ministerio de los curas, que los hay muy doctos y ejemplares, los cuales llegan a sus parroquias mediante concurso realizado ad mentem Concilii.

Hay 40 conventos, 17 de frailes y 23 de monjas, de los cuales diez están bajo la obediencia y filiación del Arzobispo. La mayoría tienen muy pocas rentas y se ven precisados a mantenerse con las limosnas de los fieles. Existen en la ciudad excelentes Hospitales: el del cardenal Mendoza para niños expósitos, donde hay más de mil, administrado por un canónigo; el de San Juan Bautista, levantado por el arzobispo don Juan de Tavera, en el que, además de acoger a los enfermos, hay un canónigo administrador nombrado por los duques de Santisteban, sus patronos, y once capellanes que tienen su coro diario en el que celebran los divinos oficios y cantan las horas litúrgicas; el de la Visitación para curar locos, conocido por el pueblo como del Nuncio; el del Rey para incurables y ancianos; el de la Misericordiá; el de San Pedro, y otros de menor entidad.Tiene también la ciudad Universidad y Tribunal del Santo Oficio de la Inquisición.

\section{Arzobispado de Toledo}

El Arzobispado de Toledo limita por oriente con el obispado de Cartagena, la ciudad de Orán y la plaza de Mazalquivir; por poniente con el de Plasencia; por el norte con el de Segovia; y por el mediodía con el de Córdoba. Las diócesis sufragáneas son Sigüenza, Córdoba, Segovia, Cuenca, Cartagena, Jaén, Osma, Valladolid, y la Abadía de Baza. Hay en la archidiócesis 732 pueblos y 823 parroquias. Se guardan fielmente los misterios de la Religión Católica, no conociéndose error común, ni particular; el Tribunal de la inquisición y los Jueces ordinarios castigan a quien temerariamente se desliza en la doctrina, y se observan puntualmente los decretos del concilio de Trento

San Eugenio, discípulo de los discípulos de los Apóstoles, es considerado como el primer obispo de Toledo, llegándose hasta el actual que ocupa el número ciento uno. Entre ellos se encuentran seis santos, seis personas reales, Infantes de Castilla y Aragón, muchos cardenales y hasta capitanes generales. La Santa Sede les concedió la dignidad de Primados de las Españas y a la mayoría de ellos el cardenalato. El Arzobispo cuenta con dos Obispos auxiliares, que residen respectivamente en Toledo y en Madrid, los cuales le ayudan a conferir las sagradas órdenes y el sacramento de la confirmación. Hay también dos Vicarios Generales, que residen el uno en Toledo, siendo normalmente canónigo o dignidad, y el otro en Alcalá de Henares. Desde tiempo inmemorial, existe un Consejo de Gobernación, compuesto por cinco consejeros, de los que el presidente y otro suelen ser canónigos y el resto personas muy vir- 
tuosas y doctas. En él se tratan los asuntos más importantes del gobierno ordinario de la diócesis, los temas que presentan los vicarios y los visitadores relativos a sus vicarías y distritos, y las apelaciones de los obispados sufragáneos.

El arzobispo de Toledo tiene además el señorío y gobierno temporal de la villa de Talavera y de los 30 pueblos de su distrito, de Cazorla y las villas de su Adelantamiento, de la ciudad de Alcalá de Henares, y de las villas de Santorcáz, Villafranca del Puente y Camarena donde nombra los Corregidores, Alcaldes Mayores y demás ministros necesarios para la buena administración de la justicia.

\section{Catedral de Toledo}

La Catedral de Toledo tiene oficio propio aprobado por la Santa Sede y, según tradición constante e ininterrumpida, fue visitada personalmente por la Santísima Virgen María honrando a su arzobispo San Ildefonso con la joya inestimable de la vestidura litúrgica que le entregó. Posee materialmente una fábrica que la hace respetable y magnífica. El rey Alfonso VI se la arrebató a los moros y de Mezquita la transformó en Iglesia cristiana. Es primorosa, tanto por su estilo gótico como por su extensión, capillas y adornos. Su longitud es de cuatrocientos cuatro pies y su anchura de doscientos dos; tiene cinco naves y descansa sobre ochenta y ocho columnas. La luz se introduce a través de sus setecientas cincuenta vidrieras; su celebre torre tiene trescientos cincuenta y nueve pies de altura y encierra doce campanas, de las que la mayor es de treinta y cinco pies de circunferencia y doce de altura, con un peso de mil quinientas cuarenta y tres arrobas. Las rentas de la catedral son copiosas y las administra el canónigo llamado Obrero. El Cabildo se rige por sus Estatutos o Constituciones, siendo muy observante de ellos, lo mismo que de las costumbres que vienen de antiguo. Los Racioneros y los Capellanes tienen cada uno su Hermandad respectiva, regida por sus Constituciones.

El conjunto de canónigos y dignidades son muy recomendables por su virtud, letras y nacimiento, llegando a Toledo normalmente por ascenso desde otras catedrales. Hay 14 dignidades, 40 canónigos, 50 racioneros, 10 canónigos extravagantes, 44 capellanes de número y otros 9 de distintas fundaciones. Todos han superado las pruebas de limpieza de sangre según el Estatuto presentado por el arzobispo Juan Martínez Silíceo y aprobado por Paulo III y Paulo IV. Asisten a coro y a las horas canónicas, celebran y cantan las Misas, por lo que tienen estas canonjías el concepto de presbiterales; los racioneros cantan los Evangelios y las Epístolas; cinco de los canónigos son de los llamados de oficio: dos doctorales, un magistral, un lectoral y un penitenciario.

La solemnidad de los oficios divinos es tanta que causa admiración ver el tesón santo con que se celebran de día y noche. Para ello hay un gran numero 
de salmistas muy diestros en su oficio y en el canto eclesiástico. El coro de música es muy completo. Son bastantes los instrumentos de música que usan, pero algunos impropios del canto eclesiástico, y nada propicios para mantener la devoción, el recogimiento y el fervor de los fieles, ocasionando frecuentemente notables distracciones y disipaciones de espíritu, por lo que convendría que se quitasen y desterrasen de los templos los violines, las flautas, y demás instrumentos cuyo uso profano es contrario a la circunspección y gravedad del templo. Existe un grupo de niños músicos que se llaman «seises», a quienes se les instruye principalmente en el canto eugeniano por un maestro que llaman de melodía, con ración y capa de coro. Hay un Colegio de niños, llamado de Infantes, con veinte becas, fundado por el arzobispo Martínez Silíceo, con la misión de ayudar en la celebración de los oficios divinos. Igualmente se sigue manteniendo el Colegio de Doncellas Nobles, para niñas, fundado por el mismo arzobispo. La costumbre diaria de la «limosna del mandato», realizada después de celebrar la Misa mayor, por la cual el Arzobispo da de comer diariamente a 30 pobres, sigue también vigente, atendiendo especialmente a los peregrinos.

La Catedral está adornada y engrandecida por 39 capillas, siendo las más notables: la de la Virgen del Sagrario, la del Corpus Christi o Mozárabe, la de Reyes Viejos y Nuevos, la de Doctores y la de San Pedro, que es también parroquia. El número de Misas que se debe celebrar por obligación es de 23.000 al año, además de las voluntarias, que suelen ser unas cien diarias.

\section{Colegiatas}

Existen en el arzobispado de Toledo 4 Iglesias Colegiales: Talavera, Alcalá, Pastrana y Escalona.

La Colegial de Talavera tiene 4 dignidades, 10 canónigos, 8 racioneros, 5 capellanes y 12 músicos; hay siete capillas y una de ellas hace de parroquia. La Colegial de Alcalá fue erigida por Sixto IV el año 1477 ante la solicitud del arzobispo Carrillo; el cardenal Cisneros consiguió en el año 1519 del papa León X que pudiese denominarse Magistral; cuenta con 5 dignidades, 28 canónigos, licenciados o doctores en teología y derecho, 1 arcipreste titular de la parroquia de Santa María, que puede ser también canónigo; y 15 racioneros, maestros en filosofía. La Colegial de Pastrana, que tiene por patronos a los duques del mismo título, y fue fundada por éstos en virtud de una bula del papa Pío V en 1583, tiene 8 dignidades, 12 canónigos, 12 racioneros, 16 capellanes y 14 oficios amovibles para el mejor servicio de la Iglesia. La Colegial de Escalona fue fundada por los duques de este título; tiene 7 dignidades, 12 canónigos, 12 racioneros y otros tantos capellanes. 


\section{Vicarías territoriales del Arzobispado}

El arzobispado de Toledo está organizado territorialmente en 9 Vicarías, con un Vicario al frente de cada una de ellas. Las cabezas de estas Vicarías se encuentran en las poblaciones de Madrid, Alcázar, Alcaráz, Orán, Cazorla, Villafranca del Puente, Huescar, Ciudad Real y Talavera.

En Madrid reside un Vicario y Visitador con su tribunal correspondiente. Hay 13 parroquias y 334 cofradías o hermandades; los conventos de frailes de diferentes Ordenes son 35, uno de ellos extramuros; los conventos de monjas son 24, con dos beateríos, de los que diez pertenecen a la jurisdicción arzobispal. Hay un Oratorio de San Felipe Neri y otro de Clérigos Misioneros del Salvador.

En la villa de Alcázar, del Priorato de San Juan de Jerusalén, reside un Vicario, Visitador ordinario y Delegado Apostólico, con las facultades necesarias para ejercer jurisdicción diocesana y apostólica delegada en 10 villas del referido territorio de la Orden de San Juan; todo con arreglo a la Concordia acordada entre las Dignidades Arzobispal de Toledo y Prioral de San Juan, aprobada por Inocencio XII el 12 de diciembre de 1698. Conforme a este acuerdo, el Gran Prior de San Juan concede la colación de 20 parroquias pertenecientes a los Religiosos de la Orden, que son presentadas ante el Consejo de Gobernación para su examen, aprobación ad curam animarum y licencia para su ejercicio. El pueblo de Villamiel es una Encomienda particular de la Orden, con separación total, y sin mas intervención del Arzobispo que para conceder la licencia ad curam animarum exercendam.

En la ciudad de Alcaraz reside un Vicario y Visitador con el tribunal correspondiente para atender a los 28 pueblos que componen la vicaría. Hay 34 parroquias, muchas fundaciones pías, capellanías y hermandades, 8 conventos de religiosos, 1 hospicio que atienden los religiosos, 4 monasterios de monjas, dos de ellos sujetos a la jurisdicción del Arzobispo, 32 ermitas, 13 oratorios públicos y 6 hospitales.

En la ciudad de Orán y en la cercana plaza de Mazalquivir, en África, reside un Vicario y Visitador Diocesano que es, a su vez, párroco y capellán mayor de la tropa.

En la villa de Cazorla reside un Vicario y Visitador que también es Juez Metropolitano de la Abadía de Baza y su territorio.

En la villa de Villafranca del Puente del Arzobispo reside un Vicario y Visitador que es, al mismo tiempo, el párroco de su Iglesia. Existe una fundación del arzobispo don Pedro Tenorio compuesta por 8 capellanes con la obligación de asistir a coro por la mañana y por la tarde y de celebrar tres Misas al día. Hay también un hospital para socorro de peregrinos y enfermos. 
En la ciudad de Huescar reside un Vicario y Visitador, quien atiende a otros 2 pueblos en aquel Partido.

En la ciudad de Ciudad Real reside un Vicario y Visitador con su tribunal correspondiente. Atiende a 40 pueblos, 26 de los cuales son de la Orden de Calatrava, en los que están establecidas 45 parroquias y 7 anejos, 29 hospitales, 179 cofradías y un largo número de ermitas, montes de piedad y otras fundaciones.

En la villa de Talavera hay un Vicario y Visitador con el correspondiente tribunal para el conocimiento de las causas en los 52 pueblos que componen la Vicaría, además de los del arcedianato titular de dicha villa.

\section{Distritos territoriales del Arzobispado}

El arzobispado de Toledo completa su organización territorial con 8 Distritos, con un Visitador encargado de visitar los diferentes pueblos del distrito cada dos años. Las poblaciones cabezas de distrito son: Canales, Zorita, Ocaña y La Guardia, Talamanca, Hita, Cogolludo y Uceda, Rodillas y Montalbán, Illescas, Alcalá y Guadalajara, Montes de Toledo y Puebla de Alcocér.

El distrito de Canales y Escalona tiene un Visitador que se encarga de 74 pueblos, en los que están erigidas 55 parroquias y 19 anejos. El distrito de Zorita, al frente del cual hay un Visitador, comprende la parroquial de Pastrana, con otros 65 pueblos, en los que hay 52 parroquias y 13 anejos. El distrito de Ocaña y La Guardia tiene un Visitador responsable de 40 pueblos, en los que están erigidas 43 parroquias y 4 anejos. El distrito de Talamanca, Hita, Cogolludo y Uceda tiene un Visitador responsable de 123 pueblos, en los que están erigidas 129 parroquias y 33 anejos. El distrito de Rodillas y Montalbán tiene un Visitador responsable de 51 pueblos, en los que están erigidas 55 parroquias y 8 anejos. Hay también un colegio para la instrucción de jóvenes en latinidad. El distrito de Illescas tiene un Visitador responsable de 20 pueblos, en los cuales hay 19 parroquias y 2 anejos, 3 hospitales para curación de enfermos y 4 albergues para transeúntes. El distrito de Alcalá, Guadalajara y Alcolea de Tajo tiene un Visitador responsable de 96 pueblos, en los que están erigidas 106 parroquias. El distrito de Los Montes de Toledo y de Puebla de Alcocér tiene un Visitador responsable de 30 pueblos, en los que hay 30 parroquias y 11 anejos, 7 hospitales para la curación de enfermos, y 2 casas para transeuntes.

\section{Comportamiento de los párrocos y estado de las parroquias}

Los párrocos residen en sus propias parroquias, las cuales se proveen en su mayor parte mediante concurso abierto. No se ausentan de ellas sin la licencia correspondiente que se les da por un tiempo moderado y con arreglo a los decretos conciliares. En cada parroquia hay libros diferenciados para inscribir las 
partidas de Bautismo, Confirmación, Matrimonio y Defunción. Existen también otros libros en los que se anotan las Fundaciones piadosas, los bienes de cada Iglesia y su estado, con las cuentas que se toman en cada Visita de las rentas y de su distribución. Hay, igualmente, libro de las Capellanías allí fundadas, libro de Memorias de legos con cargas pías y libros de Cofradías, Hospitales, Montes de Piedad y semejantes. Todos se custodian en un Archivo y se hace de ellos el uso correspondiente en las Visitas. Los párrocos cumplen con la explicación del Santo Evangelio y de la doctrina cristiana y se tienen conferencias morales y de liturgia. Las Misas se aplican pro populo en los domingos y fiestas de precepto. Las sacristías de todas las parroquias tienen colgadas la Tabla con la descripción del número de misas y aniversarios de fundaciones piadosas que se deban cumplir según la voluntad de sus fundadores. Las fábricas materiales de dichas parroquias están bien reparadas y surtidas de ornamentos, alhajas y vasos sagrados. Todos los Visitadores dan cuenta ante el Consejo de Gobernación de cuanto han realizado en sus respectivas visitas, indicando al Arzobispo respecto a los párrocos, vicarios y demás eclesiásticos lo que necesita reforma, tanto en la conducta como en la vida o las costumbres.

\section{Temas objeto de preocupación pastoral}

El gran número de pobres existentes en la ciudad de Toledo y en el arzobispado constituía una gran preocupación para el cardenal Lorenzana. Para ayudarles eficazmente funda una gran Casa de Caridad en Toledo y consigue que el Rey Católico le done el magnífico edificio del Alcázar.

El Convento de San Bartolomé en la ciudad de Valladolid, perteneciente a las RR. Trinitarias, por problemas y desavenencias en su gobierno, fue encomendado hace muchos años a los arzobispos de Toledo. El cardenal Lorenzana sugiere a Roma que, dado que está muy lejos de Toledo y que la ciudad ya cuenta con un obispado, buscando el bien y la disciplina de las religiosas, podría encargarse el cuidado y gobierno de dicho monasterio al obispo de Valladolid.

Un motivo de grandísima preocupación lo constituye para el cardenal Lorenzana el problema de los privilegios que gozan los pueblos que, estando dentro del territorio diocesano, pertenecen a las Ordenes Militares de Santiago y Calatrava y, fundamentalmente, la exención de que hacen gala los párrocos y demás eclesiásticos no obedeciendo las indicaciones ni requerimientos del Arzobispo, que busca siempre el bien espiritual de los fieles. El cardenal deja constancia de que los párrocos sujetos a los Ordenes Militares no guardan la residencia en sus parroquias y que encomiendan a otros clérigos menos preparados el gobierno de sus Iglesias, como si fuesen simples beneficios; que no acuden a recibir el visto bueno de la jurisdicción arzobispal y, que si lo hacen, no respetan luego acuerdo alguno o instrucción; y que el interés que se toma el 
Arzobispo queda siempre frenado por el recurso que inmediatamente presentan las Ordenes Militares ante la Junta Apostólica.

El excesivo número de conventos existentes en el Arzobispado y los abusos que en ellos se cometen son, según indica el cardenal Lorenzana en el Informe, un problema que requiere una pronta solución. Al ser tantos, no tienen suficientes rentas para una digna sustentación y por ello deben salir por las calles pidiendo limosnas y abandonando el retiro de sus claustros y la disciplina, siendo gravosos a los lugares a donde acuden a pedir limosna y viviendo externamente como simples seglares. Esto se solucionaría si se cumpliesen las normas del concilio de Trento que estableció que las Comunidades Religiosas recibiesen solamente el número de personas que pudiesen mantener con sus rentas y limosnas ordinarias.

Finalmente, señala el cardenal Lorenzana, existe otro tema en el que le gustaría que desde Roma interviniesen cambiando la legislación al respecto. Muchas villas y lugares de la diócesis en donde se habían erigido parroquias se han despoblado y por disposición de Nicolás $\mathrm{V}$ las fábricas de sus templos y sus rentas pasan a ser propiedad de la Hermandad de Racioneros de Toledo. Semejante privilegio conduce a que se abandonen muchos lugares por parte de los párrocos, argumentando que no hay fieles suficientes para ser considerada parroquia, con lo cual no tienen obligación de guardar la residencia y procuran encomendar esos lugares a unos lugartenientes sin interés ni preparación, convirtiéndose en beneficios simples.

Termina el Informe el cardenal Lorenzana, indicando al Santo Padre que éstos eran los principales abusos, dignos en verdad de ser tenidos en cuenta, confiando su remedio a la comprensión y acreditada prudencia de S.B. de la que esperaba recibir las advertencias y enseñanzas a practicar para el mejor acierto de un gobierno tan dilatado, y tan desigual a sus fuerzas. En lo que éstas alcanzaban, procurara trabajar incesantemente para desempeñar las obligaciones de su ministerio. En esta situación únicamente deseaba la benévola bendición de S.B. y las saludables instrucciones de la Santa Sede, las cuales serían un gran consuelo, como dictadas por la Cabeza de la Iglesia, a quien el todopoderoso guarde feliz los años que la Cristiandad tenga necesidad y convenga.

\subsection{Informe del cardenal Lorenzana en $\mathbf{1 7 8 0}$}

Después de expresar sus buenos deseos al Santo Padre y de indicar que quiere seguir los pasos rectos de sus antecesores, el cardenal Lorenzana describe el estado de la diócesis toledana según se encontraba en el año 1780. Resaltamos del Informe los datos más destacados. 
Toledo: diócesis, lugar, límites, obispos, pueblos y parroquias

La ciudad de Toledo se asienta sobre una colina que se asoma al río Tajo que la rodea, está situada en la antigua provincia Carpetana, hoy Castilla La Nueva. Recibe el nombre de regia e imperial desde que los reyes Alfonso VII y Alfonso VIII fueron llamados emperadores, y también por Alfonso X, electo emperador aunque no reconocido. La ciudad fue primero del reino de los Godos, después de los Moros hasta que fueron expulsados por el rey Alfonso VI y la declaró sede de su reino. Su escudo muestra a un Emperador sentado, con una espada desenvainada en la mano derecha y el globo terráqueo en la izquierda. El escudo de la catedral representa la Descensión de la Virgen e imposición de la casulla a San Ildefonso, por su defensa de la virginidad contra Elvigio, Pelagio y sus seguidores.

La diócesis limita al norte con Cartagena, y más allá, en las costas africanas, con el mar Mediterráneo y las ciudades de Orán y Mazalquivir; por el oeste con Plasencia; por el norte con Segovia; y por el sur con Córdoba. Son obispados sufragáneos los de Sigüenza, Córdoba, Segovia, Cuenca, Cartagena, Jaén, Osma, Valladolid y la abadía de Baza en la diócesis de Guadix. En toda la archidiócesis hay 732 pueblos y 823 parroquias. La diócesis mantiene la fe y no hay en ella herejía alguna. Un Tribunal de jueces eclesiásticos se cuida de ello.

La diócesis de Toledo se ha visto siempre adornada de notables Arzobispos, hasta ahora 101, todos esclarecidos por su virtud y letras. Entre ellos destacan San Eugenio, enviado por los discípulos de los Apóstoles a España, seis arzobispos santos, seis hijos de los reyes de Castilla y Aragón, algunos caudillos de ejércitos como Gil de Albornoz que logró restituir a la Iglesia sus posesiones, y muchos cardenales insignes de la Iglesia como Rodrigo Jiménez de Herrada, Martín López de Pisuerga, Pedro González de Mendoza o Francisco Jiménez de Cisneros.

\section{La catedral de Toledo}

Según cuenta la tradición, la Catedral de Toledo fue ennoblecida con el milagro de la Descensión de la Santísima Virgen María, quien revistió a San Ildefonso con una celestial casulla, premiando así la defensa que había hecho de su virginidad con el tratado «De Virginitate». Es un edificio espectacular. Fue anteriormente Mezquita y Alfonso VI después de conquistar la ciudad la convirtió en Catedral para los cristianos. Fue sin embargo el rey don Fernando quien inició la construcción del templo actual. Sobresale por su arquitectura de estilo gótico, por su amplitud, por su hermosura y por sus capillas. Tiene cuatrocientos pies de larga y más de doscientos de anchura, sin contar las Capillas. Está dividida en cinco naves, tiene noventa y dos columnas y numerosas vidrieras pinta- 
das a fuego. Su admirable torre mide trescientos cincuenta y nueve pies, y tiene doce campanas, siendo la mayor de ellas de treinta y cinco pies de circunferencia, doce de alto y con un peso de cuarenta mil ciento veintiocho libras. El Canónigo Obrero es la persona que se encarga de su vigilancia y conservación.

El Cabildo está formado por un colectivo de dignidades y canónigos imitables por su virtud y letras. Hay 14 dignidades, 40 canónigos, siendo una de sus canonjías para el Tribunal de la Inquisición, 50 racioneros, 10 canonjías extravagantes, 44 capellanes de número y otros ministros pertenecientes a otras nueve fundaciones. Todos cumplen con su oficio según las normas de la Iglesia y con el Estatuto establecido por el arzobispo Juan Martínez Silíceo. A los treinta y nueve canónigos les incumbe la obligación de decir o cantar la misa, de asistir a coro y cantar las horas. Para ser canónigo se exige estar ordenado de presbítero. Los racioneros se encargan del canto de la epístola y del evangelio. Cinco canónigos ejercen los oficios de magistral, lectoral, penitenciario y dos doctorales. A lo largo del año se celebran en la Catedral en torno a veintitrés mil misas.

Es grande la solemnidad que se observa en la celebración de los divinos oficios, cumpliendo día y noche cada uno con su obligación. Existe un número importante de salmistas que se turnan durante el día, la noche y de madrugada. Respecto de la música, existe un número importante de músicos y muchos instrumentos musicales; algunos de ellos no ayudan al fervor y devoción de los fieles, sino a su distracción. Sería conveniente suprimir la flauta demasiado aguda y otros sonidos parecidos; igualmente habría que eliminar los instrumentos de cuerda pues al ser de uso profano no ayudan a guardar el respeto y honor debido en el templo. Pero, para llevar adelante esta decisión, no basta la autoridad del Prelado, sino que se requiere también el respaldo de la autoridad Apostólica y Real.

Existe un Colegio de niños, llamados «seises», que cantan el canto antiguo toledano o de San Eugenio. Con ellos está como responsable un racionero conocido como el Maestro de Melodía. Para ayudar en los oficios divinos, el arzobispo Juan Martínez Silíceo fundó el Colegio de Infantes. En un primer momento eran 40 los clerizones que lo componían, ahora son sólo 20. Hay nombrados un Rector y un Maestro de Gramática que se encargan de ellos y el Cabildo, mediante dos canónigos nombrados al efecto, vigilan su buen funcionamiento. Sería mi intención, indica el cardenal Lorenzana, transformarlo en un colegio según la mente del concilio de Trento, pero no es fácil cambiar los derechos que sobre él tiene el Cabildo.

La Catedral está adornada de 39 Capillas, siendo la principal la del «Sagrario», construida por el cardenal Sandoval y Rojas y en la que se venera a la Virgen del Sagrario. Es la patrona de la ciudad y del cabildo. Está toda ella 
revestida de mármol, jaspe, bronce dorado y otros materiales preciosos, en arte dórico y corintio. En la parte interior de la misma se encuentra otra preciosa estancia con muchas y preciadas reliquias, como los cuerpos de San Eugenio y de Santa Leocadia.

Del resto de las capillas destacan: la Capilla del Corpus Christi o Mozárabe, con nueve capellanes, donde diariamente se celebra la misa y el oficio divino en este antiguo rito gótico o isidoriano; la Capilla de Reyes Viejos, erigida por Sancho IV, con cuatro capellanes de nombramiento real, que celebran la misa cantada por los Reyes en los días señalados; la Capilla de los Reyes Nuevos, mandada construir por Enrique II, con 24 capellanes que celebran diariamente la misa y el nocturno de difuntos, y en la que se integró la capilla de las reinas Juana y Catalina; la Capilla parroquial de San Pedro, que se cuenta como una parroquia más de Toledo, engrandecida por el cardenal Sancho de Rojas; tiene una canónigo capellán mayor y doce capellanes menores y para la administración de los sacramentos tiene dos párŕcos, uno por concurso y otro nombrado por el Cabildo; y la Capilla de Doctores, próxima a la del Sagrario, erigida por el arzobispo Bernardo Sandoval y Rojas con siete capellanes doctores o licenciados.

\section{Parroquias, monasterios, instituciones}

Seguidamente, y después de indicar las pensiones con las cuales estaba grabada la Dignidad Arzobispal, el arzobispo Lorenzana se refiere al estado y número de las parroquias, monasterios y otras instituciones sociales o de caridad existentes en el Arzobispado.

En la ciudad de Toledo hay 25 parroquias, 19 de rito romano y 6 de rito mozárabe. Hay también, 40 conventos, 17 de frailes y 23 de monjas. De ellos, 10 están sujetos a la obediencia del Arzobispo y el resto a sus Prelados Regulares. En todas las parroquias y conventos se fundaron numerosas cofradías que son vigiladas por los Visitadores.

Los párrocos, cuya principal tarea es la predicación, son nombrados previo examen y en concurso abierto. Son examinados de teología, derecho y moral. En cada parroquia llevan con sumo cuidado, siguiendo las normas sinodales, los Libros de Bautismo, Confirmación, Matrimonios y Defunciones. No faltan tampoco los libros de Obras Pías, Fábrica de la Iglesia, Patronatos, Confraternidades y de diversas Fundaciones. Todos se conservan en el Archivo, que es revisado por los Visitadores en su visita canónica.

En la ciudad de Madrid hay 34 monasterios de religiosos varones de diversas Ordenes y 24 monasterios de mujeres, doce de los cuales están bajo la obediencia del Arzobispo. Existen dos casas de Beatas y una institución de patronato regio para la acogida y educación de niñas nobles. Están erigidos en la ciudad los Oratorios de San Felipe Neri, del Santísimo Salvador y otros de 
sacerdotes seculares, donde se enseña el catecismo, se educa en la fe a los fieles y se promueven obras de caridad y misericordia.

Pervive en Toledo el Colegio de Doncellas Nobles, o de la Virgen de los Remedios, fundado por el cardenal Silíceo para educar cómoda y honestamente a cien jóvenes, quienes reciben su dote en el momento de elegir estado. Igualmente, el Orfanotrofio u hospital de niños expósitos, fundado por el cardenal Mendoza para la atención a cien niños, donde el Cabildo nombra su Rector y administra sus rentas; y los hospitales para ancianos, enfermos incurables, clérigos pobres y transeúntes, conocidos como Hospital Tavera, Hospital de la Visitación, Hospital del Rey, Hospital de San Pedro.

\section{Gobierno y organización de la diócesis}

El Arzobispo cuenta con dos Obispos auxiliares, concedidos por la Santa Sede, uno reside en Madrid y el otro en Toledo. Visitan la diócesis administrando el sacramento de la Confirmación, las órdenes sagradas y realizan otras tareas propias de su ministerio episcopal. Hay desde antiguo un Consejo de Gobernación (sobre el que describe sus fundamentos y competencias), formado por canónigos y peritos en leyes. Existe un Superintendente de Religiosas.

A continuación, enumera los distintos Vicariatos de la archidiócesis, haciendo referencia a su fundación, situación, número de parroquias y organización; las Iglesias Colegiales; y los Distritos en los que se encontraba dividido el territorio diocesano, con su organización, número de parroquias y forma de gobierno. Al frente unos y otros estaban los Vicarios y Visitadores.

Vicarías: Madrid, Alcázar de San Juan, Alcaraz, Orán, Cazorla, Villafranca de la Puente del Arzobispo, Huescar, Ciudad Real, y Talavera.

Iglesias Colegiales: Talavera, Alcalá de Henares, Pastrana, y Escalona.

Distritos: Canales, Zorita, Ocaña y La Guardia, Talamanca, Hita, Cogolludo y Uceda, Rodillas y Montalbán, Illescas, Alcalá y Guadalajara, Montes de Toledo y Puebla de Alcocer.

Señorío temporal: Talavera y su comarca, Adelantamiento de Cazorla, Alcalá, Santorcáz, Puente del Arzobispo y Camarena.

Siguen las contiendas y pleitos por problemas de jurisdicción con las Ordenes Militares de Santiago y Calatrava.

\subsection{Informe del cardenal Lorenzana en 1784}

El cardenal Francisco Antonio Lorenzana, fiel a las normas de Roma, pasados cuatro años, de nuevo cumple con la obligación de realizar la visita ad limina y de 
presentar un Informe. El presente será breve y centrado en algunos temas del momento, pues en el informe anterior ya había resaltado los aspectos generales y comunes existentes en el arzobispado. Inicia la narración con el saludo al Santo Padre y la petición de disculpas por no realizar la visita personalmente.

A continuación expone que, en unión del Cabildo de la Catedral y siguiendo las directrices de la Sagrada Congregación, estaba tratando de remodelar el Colegio de Infantes según las normas del concilio de Trento. Igualmente, estaba realizando un intento de avenencia con la Ordenes Militares de Santiago, Calatrava y San Juan de Jerusalén. También, aconsejado por el Sr. Nuncio, trataba de ajustar o situar a la Rota española en el lugar que le correspondía. Con el Consejo Real todo seguía en el mismo lugar con gran perjuicio para los negocios de ambas jurisdicciones.

Recuerda, seguidamente, que su antecesor en la sede toledana, el cardenal Fernández de Córdoba, hizo público un sabio edicto regulando y unificando la Exposición del Santísimo Sacramento de manera que ésta no se celebrase de cualquier manera y con cualquier causa sin antes solicitar la debida autorización del Ordinario. Esta norma no era cumplida por los religiosos, aduciendo estar exentos y tener facultades apostólicas para realizarla según sus criterios en ciertas fiestas. El cardenal Lorenzana solicita ahora al Santo Padre que mande a los religiosos obedecer las normas del Ordinario, buscando así el bien de los fieles al realizar este culto. Y, de la misma manera que solicitaban al Ordinario licencias para poder confesar y predicar, deberían unificarse con en resto del clero en unas mismas normas para realizar el culto a la Eucaristía. Señala, finalmente, que en Madrid no cumplían tampoco las normas del papa Urbano VIII para la Exposición del Santísimo, pues no lo hacían en el altar mayor, no se cubrían las imágenes, ni alternaban cantos espirituales, ni permanecían al menos dos personas velando junto al Santísimo, y ni siquiera el sacerdote estaba allí asiduamente, sino que se ausentaba sin causa justa y dejaba en su lugar a personas privadas.

\subsection{Informe del cardenal Lorenzana en 1788}

El Informe que el cardenal Lorenzana presenta en Roma el año 1788, es una narración interesantísima por el contenido que refiere: la visita pastoral que realizó personalmente a la ciudad de Orán, en el norte de África, y el paso, al ir y al regresar, por lugares de la diócesis apartados de la ciudad de Toledo y raramente visitados por el Arzobispo.

Escribe el cardenal Lorenzana al Santo Padre que, siendo la principal tarea de un Pastor apacentar el rebaño y con su presencia alegrarlo y animarlo, él lo 
había procurado realizar así desde que se hizo cargo del arzobispado de Toledo, y que siempre había sido su propósito acercarse hasta la lejana ciudad de Orán en cuanto las circunstancias fuesen oportunas. Habiendo realizado este viaje, daba ahora cuenta de ello a Su Santidad.

El viaje hasta Orán desde siempre se había visto como una empresa difícil de realizar, pues existía guerra contra los africanos y los mares estaban infestados de piratas que ponían en peligro cualquier intento de navegación hasta allí. Para no ser atacados por los bárbaros, se llego a un pacto con el Rey africano y, apoyados por el Rey Católico que puso a nuestra disposición una de sus naves en el puerto de Cartagena, nos dispusimos a iniciar la marcha.

Con valor y diligencia comenzamos el viaje el día 17 de las kalendas de mayo de 1786 desde Toledo hasta Cartagena. Y mientras atravesábamos la diócesis nos fuimos parando en cada población, amonestando con nuestra predicación al clero y al pueblo a cumplir con sus respectivas obligaciones. Finalmente, después de diez días de viaje, llegamos a Murcia donde fuimos recibidos por el Obispo de la diócesis, quien nos acompañó hasta Cartagena una vez que hubimos descansado durante tres días. Habiendo embarcado, tuvimos que esperar la salida de la nave otros doce días a causa de unos fuertes vientos. Mientras tanto, compartimos con el obispo diocesano mutuas pruebas de afecto y le ayudamos a causa de su delicado estado de salud a administrar el sacramento de la Confirmación y a predicar al pueblo.

Poco antes de partir se desató una gran tempestad. Pasada ésta, el día 11 de mayo, estando todo preparado, subimos al barco y nos hicimos a la mar, y antes de transcurrir treinta horas de navegación llegamos al puerto de Orán, siendo recibidos por un gran número de gente con aplausos y expresiones de alegría, pues no veían a su Arzobispo desde tiempos del cardenal Cisneros, aunque los Obispos auxiliares había visitado regularmente esta Vicaría para que el pueblo cristiano no se viese desatendido.

Mientras estuvimos allí, buscamos solamente cumplir con los deberes de un Pastor. Visitamos solemnemente la Iglesia y nos preocupamos con asiduidad y constancia de la vida y costumbres de los ministros de la Iglesia, a la vez que amonestamos al Vicario para que llevase una buena administración. Conferimos órdenes sagradas, escogiendo algunos jóvenes que habían dado pruebas de honradez y les inscribimos en el número de los clérigos. Al celebrarse aquellos días la fiesta del aniversario de la liberación de la ciudad de manos de los moros por los Reyes Católicos, Isabel y Fernando, celebramos una Misa solemne en acción de gracias, acompañados del clero, del Jefe de la milicia y del pueblo allí presente. Socorrimos a los pobres, a los enfermos de los hospitales, a los presos y los huérfanos, sin olvidarnos de los condenados a trabajos forzados, y, en general, procuramos ayudar a todos. Y no solamente el Arzobispo 
sino también sus acompañantes, quienes a lo largo de estos días enseñaron al pueblo y oyeron sus confesiones.

Realizada la tarea pastoral prevista, nos dispusimos a regresar antes de que alguna tormenta nos impidiese embarcar. Salimos de Orán el día 22 de mayo y en un viaje no tan bueno como el de ida, pues hubo mareos y tardamos dos días y medio, llegamos al puerto de Cartagena, donde permanecimos un día para reponernos.

La vuelta a Toledo la realizamos por la parte de la diócesis que aún no conocíamos y que se encuentra entre las diócesis de Almería y Jaén. En dicho viaje empleamos casi dos meses, recorriendo caminos estrechos y malos, después de atravesar tierras solitarias. El amor a los fieles y el deseo de enseñarles la doctrina nos empujaba a seguir. Después de un camino de cuatro días llegamos a Huescar, donde empleamos todo el día en confirmar y enseñar al pueblo. Visitamos las Iglesias y proveímos a sus necesidades. Nos dimos cuenta que por estar tan diseminados apenas podían acercarse a las parroquias una vez al año. Por ello, escogimos algunos presbíteros de gran virtud y ciencia para que les atendiesen adecuadamente y les administrasen los sacramentos.

Fuimos después al territorio de Cazorla para confirmar y predicar por todos sus pueblos y visitar sus Iglesias. Esta ciudad y sus pueblos fueron arrebatados a los moros por el arzobispo de Toledo don Rodrigo Jiménez de Rada y entregada a la Dignidad Arzobispal como beneficio por los Reyes Católicos. Realizada la tarea, a mediados de junio, por Almagro y Ciudad Real regresamos sanos a Toledo.

Termina la narración el cardenal Lorenzana, expresando al Santo Padre la esperanza de que el Informe le haya sido grato al comprobar que tanto antes como ahora los Pastores de la Iglesia Apostólica siguen cumpliendo con su ministerio en todas partes.

\subsection{Informe del cardenal Lorenzana en 1792}

El informe presentado por el cardenal Lorenzana en 1792 es también breve. Cumple con la obligación de visita ad limina y presenta a la Sede Apostólica aquellos hechos conseguidos o dificultades aparecidas. Se excusa de no ir personalmente y ruega se le conceda la gracia de realizar la vista a través de un delegado.

Manifiesta el cardenal Lorenzana que, tanto en los años anteriores como en los presentes, había procurado cumplir siempre y fielmente con sus deberes de Pastor. Por ello, nunca había dejado de exhortar a los párrocos para que, lo mismo que la Sabiduría Eterna de Dios descendió a la tierra, ellos se compor- 
tasen como pequeños en medio de los hermanos, enseñasen con estilo sencillo y claro los misterios de la santa religión, instruyesen en los preceptos relativos a la vida y costumbres cristianas, alimentasen con el manjar de la sana y eterna doctrina, y alejasen a los fieles de las novedades y peregrinas afirmaciones que suelen dañar el ánimo y la piedad cristiana.

Ante la existencia en Ciudad Real de un número tan grande de personas necesitadas de alimentos, ropas y de aprender un oficio, como se había encontrado en la visita a la ciudad, el cardenal Lorenzana había comenzado a construir un Albergue para pobres que esperaba que se inaugurase próximamente.

Tenía el propósito, cumpliendo así las indicaciones de los Sumos Pontífices y las prudentes normas del concilio de Trento, de realizar la visita canónica a la Iglesia de Toledo, la cual no se realizaba desde muchos años atrás, con el fin de promover el culto divino, extirpar los defectos y procurar el decoro de la Iglesia.

Estaba a punto de ver finalizada la construcción del nuevo Hospital para dementes en Toledo. El anterior, administrado por el Cabildo, con el paso de los años se encontraba en un estado lamentable por el número tan grande de enfermos y por las pésimas condiciones del edificio. El nuevo se encontraba en un lugar soleado y con buen aire, con vistas al campo y a un cercano balneario, era grande, saludable y con gran capacidad, hecho que favorecería la recuperación de muchos enfermos.

Termina el Informe, afirmando que trata de contagiar de buenos sentimiento y de buenos ánimos a sus Vicarios, Jueces, Párrocos, nobles ricos y fieles todos, y que puede asegurar al Santo Padre que se están cumpliendo en la archidiócesis los decretos del Concilio de Trento, sin que existan errores contrarios a la fe católica, conservando en toda su pureza la religión.

\subsection{Informe del cardenal Lorenzana en $\mathbf{1 7 9 6}$}

Escrupulosamente, pasados los cuatro años preceptivos, el cardenal Lorenzana vuelve a presentar en Roma, en 1796, el qué será el último de sus Informes como arzobispo de Toledo.

Completando lo ya referido en informes anteriores y destacando ahora los aspectos nuevos del estado de la diócesis toledana, indica que había realizado la Visita pastoral en la Vicaría de San Juan, ayudado por el obispo titular de Caristo y auxiliar suyo, durante la cual había administrado en cada uno de los lugares visitados el sacramento de la Confirmación y había realizado el resto de las tareas propias de su ministerio episcopal. Igualmente, habían realizado posteriormente la Visita en la Vicaría de Alcaráz, ejerciendo así su oficio de Pastor. Invitado por el Prior del Convento de Uclés de la Real Orden Militar de 
Santiago había administrado, ayudado también de la presencia del Obispo auxiliar, el sacramento de la Confirmación en todos los lugares y castillos sujetos a este Priorato.

No debía silenciar que había construido un nuevo y amplio edificio para Hospital de enfermos mentales, ampliando enormemente su capacidad y las posibilidades de una mejor atención en todos los aspectos, pues la casa que tenían hasta el momento estaba muy deteriorada, era pequeña y muy limitada para el gran número de enfermos existentes. La administración del mismo seguía dependiendo del Cabildo de Toledo.

Había puesto todo el interés que le correspondía como obispo, como Inquisidor General y como Delegado Apostólico para que fuese conocida la Bula por la cual se condenaba el Sínodo celebrado en Pistoya.

Consciente de los tiempos tan difíciles que estaba atravesando la Iglesia, acosada por los enemigos, tenía la esperanza de poder aminorar las calamidades presentes que estaban soportando tantos buenos obispos y sacerdotes franceses emigrados a España por la cruel persecución que sufrían en Francia. Privados de sus diócesis, perseguidos, expulsados, escondidos, emigrantes... recordaban la experiencia de los primeros cristianos y de San Pablo. Con sus propias rentas, con la ayuda de otros obispos, con la de los Superiores de las Ordenes Religiosas, de Cabildos catedralicios, y de párrocos estaba procurando aliviar su indigencia y facilitarles la estancia en Monasterios y en piadosos domicilios, así como lo necesario para vivir y la diaria limosna de la misa.

Termina el Informe del cardenal Lorenzana expresando sus deseos de que cesen las calamidades presentes en Francia, vuelva la paz, sean reconocidos y erradicados los errores y vuelvan al seno de la Iglesia.

En la respuesta preparada en Roma a la vista de este Informe, se indica que no se puede sino alabar enteramente la piedad y el celo verdaderamente edificante del arzobispo de Toledo por todo lo que ha hecho y hace por el bien de los pueblos y de la Religión; que recuerde cómo en las Bulas de Sixto V y de Benedicto XIII quedan expresados estos deberes propios de los obispos; y que, como ya ha presentado en otras ocasiones extensamente informes sobre el estado material y formal de la Iglesia de Toledo, en las próximas ocasiones bastará con que brevemente indique su estado formal, transmitiendo a la Sagrada Congregación aquellos hechos nuevos referentes a su atención a la diócesis, a sus propios deberes, al estado del clero, de las monjas y religiosos, de las hermandades y del pueblo. 


\section{APÉNDICE DOCUMENTAL:}

\subsection{Informe ${ }^{11}$ del arzobispo don Francisco Antonio Lorenzana. Año 1776}

\section{[Beatisimo Padre]}

\section{Ciudad de Toledo. Sus armas}

La Imperial Ciudad de Toledo ha sido Corte de los Godos; y después de la expulsión de los Moros, de los reyes sus sucesores: tiene por Armas un Emperador sentado en su trono con espada desnuda en su mano derecha, y un Mundo en la izquierda: La Iglesia tiene por sus Armas la Descensión de María santísima, quando vajó aponer la preciosa vestidura a san Ildefonso.

\section{Su situación}

La situación de Toledo es en Castilla la nueva, sobre una eminente cumbre a la Rivera del Rio tajo: Residen en ella el Intendente de Rentas y un Corregidor; tiene Ayun$\operatorname{tam}^{\text {to. }} \mathrm{y}$ demás oficios del Publico.

\section{Terminos del Arzobispado}

El Arzobispado confina por oriente con el Obispado de Cartagena comprendiendo la Ciud ${ }^{\mathrm{d}}$. de Oran y Plaza de Mazalquivir; Por Poniente con el Obispado de Plasencia; Por Norte con el de Segovia; y con el de Cordova por Mediodia. Cuenta en la Diócesis setecientos treinta y dos Pueblos, y ochocientas veinte y tres Parroquias: Sus diócesis sufragáneas son Sigüenza, Cordova, Segovia, Cuenca, Cartajena, Jaen, Osma, Valladolid, y la Abadía de Baza.

\section{Arzobispos}

San Eugenio Discipulo de los Discipulos de los Apostoles es reconocido por el primer Obispo de Toledo: El numero de Prelados que oy se cuentan en esta Iglesia es el de Ciento y uno, sobresalientes los más en virtud, doctrina, y sangre; Entre ellos se hallan seis santos, seis Personas Reales Infantes de Castilla y Aragon, muchos Cardenales, y hasta Capitanes Generales, pues Arzobispos de Toledo fueron los Albornoces (de feliz memoria acia esa santa sede), Mendozas y Cisneros. Y así tiene esta Mitra varios Señorios, no tanto por espontanea liberalidad de los Monarchas, quanto por recompensa a sus muchos servicios, y grande fidelidad.

Como desde los principios empezasen los Prelados de Toledo a descollarse santamente sobre el resto de los demás de estas Provincias, se empeñaron tambien los Reyes Catholicos en colmarles de honras, y la Silla Apostolica en ensalzarlos, elevandolos sobre los demas, dandoles el Primado de las Españas, y visti[en]doles frecuentemente con la Purpura de su Sacro Colegio: Y asi ha merecido esta villa a los Sumos

11 ASV, Congregación del Concilio, Relationes Dioecesium, Toletana 805-B. 
Pontifices Urbano III, Inocencio III y otros sus elogios llenos de las mas altas y particulares expresiones, llamandola en sus Bulas Noble, y famosa Iglesia Toledana, propia y especial Hija de la Silla Apostolica.

\section{Misterios de la Fee}

Conserva fielmente toda esta Diocesis los Misterios de nuestra Catholica Relijion, no conociendose error comun, ni particular, castigando a qualquiera quetemerariamente se desliza, el Tribunal de la Santa Inquisicion, y los Jueces Ordinarios Ecclesiasticos, y observandose conpuntualidad los Decretos del Santo Concilio de Trento.

\section{Titulos de la Dignidad Arzobispal}

La Dignidad de Chanciller maior de Castilla es uno de los titulos de mi Mitra; Su ereccion fue el año de mil ciento treinta y cinco, y regularmente ricahía en mis Predecesores, hasta que en el Arzobispo $\mathrm{D}^{\mathrm{n}}$. Pedro Gonzalez de Mendoza nombrado Chanciller por el Rey $\mathrm{D}^{\mathrm{n}}$. Enrique $4^{\circ}$. le anexaron a otra Dignidad los Reyes Catholicos.

\section{Adelantam $^{\text {to }}$. maior de Cazorla}

Tiene tambien el Adelantamiento maior de Cazorla con sus villas, por haverle ganado a los Moros el Arzobispo $\mathrm{D}^{\mathrm{n}}$. Rodrigo Ximenez de Rada, por lo que se le dio a esta Mitra.

\section{Oran}

Asi mismo govierna en lo espiritual la Plaza de Oran y sus castillos en la Africa, que conquisto el Arzobispo $\mathrm{D}^{\mathrm{n}}$. Fray Fran ${ }^{\mathrm{co}}$. Ximenez de Cisneros en tiempo de los Reyes Catholicos $\mathrm{D}^{\mathrm{n}}$. Fernando y $\mathrm{D}^{\mathrm{a}}$ Ysabel, en cuia memoria sele dejo a la Dignidad Arzobispal aun despues de la ultima conquista.

El Rey Felipe V queriendo que esta Mitra como Primada de las demás, se distinguiese de ellas en el tratam ${ }^{\text {to }}$. la dio el de Excelencia propio de los Grandes de España, y sus Consejeros de Estado; como consta en su $\mathrm{R}^{1}$. Decreto expedido en nueve de enero demil setecientos veinte y dos.

\section{La S ta $^{\text {Iglesia de Toledo }}$}

La Santa Iglesia Cathedral de esta Ciudad merecio, seguntradiccion constante no interrumpida, y Aprovada por la silla Apostolica con Rezo propio, ser visitada personalmente de María santisima, quando honrò a su siervo san Ildefonso con la Joya inestimable de aquella vestidura que le dió.

\section{Fabrica material de ella}

Su Fabrica Material en todo la hace respetable y magnifica. Fue felizmente convertida de celebre Mezquita de Moros, en sumptuosa Iglesia de los Christianos luego que la recobró el Rey $\mathrm{D}^{\mathrm{n}}$. Alonso VI. Es primorosa, tanto en la Arquitectura Gothica, como 
en su estension, Capillas y adornos: su longitud es de quatrocientos y quatro pies, y su latitud de doscientos y dos. Está repartida su grande máquina en cinco Naves, sin contar las dos Colaterales de las Capillas, y descansa sobre ochenta y ocho columnas, comunicandola sus luces setecientas y cincuenta vidrieras: su celebre torre tiene de altura trescientos cincuenta y nueve pies, y encierra doce campanas, de las que la maior es de treinta y cinco pies de circunferencia, y doce de altura, y asciende su peso a mil quinientas quarenta y tres arrovas.

\section{Renta de la Fabrica}

La Renta de la Fabrica de que cuida el Prelado, es muy copiosa, y se administra por un Canonigo, que se llama Obrero, con oficina dentro de la misma Iglesia, y Ministros correspondientes para la formacion de Cuentas, que cada año reconoce el Cabildo por sus Canonigos Visitadores.

\section{Cabildo}

El Cuerpo de Canonig[os] y Dignidades es muy recomendable por su virtud, letras y nacimiento, viniendo aqui por ascenso regularmente de otras Cat[he]drales: el numero de Canonigos es de quarenta; y uno esta agr[e]gado al Tribunal del Santo oficio de la Inquisicion: Hay cator[ce] Dignidades, Cincuenta Racioneros, diez Canonigos que se llaman extravagantes, quarenta y quatro Capellanes de Numero, y ot[ros] nuebe de distintas fundaciones: todos justifican limpieza de sangre con arreglo a las Bullas de los sumos Pontifices Paulo III y Paulo I[V] obtenidas ainstancia del Card ${ }^{1}$. Arzobispo $\mathrm{D}^{\mathrm{n}}$.Juan Martinez Si[li]ceo, que formó este Estatuto. Es del cargo de otros treinta y nueve [Ca]nonigos ademas de la asistencia a Coro y Horas canonicas [el] celebrar y cantar las Missas por lo que tienen estas Canongia[s] el concepto de Presbiterales: Los Racioneros cantan los Evangelios, y Epistolas: Cinco de los referidos Canonigos son de Oficio, los dos Doctorales, un Magistral, un Lectoral, y un Penitenciario.

\section{Celebracion de los Divinos Oficios y Coro de Musica}

La solemnidad de los Divinos Oficios es tanta, que causa admiracion ver el tesón santo con que se celebran de dia y noche. Para esto tiene un gran numero de Psalmistas muy diestros en su oficio y canto ecclesiastico, qie rijen unos de dia, y otros en los Maytines que se cantan a media noche: el Coro de Muisica es muy completo: Por Bullas Pontificias estan agregadas algunas Raciones a Ministros del Coro: Son bastantes los Instrumentos de Musica, pero algunos impropios del Canto Ecclesiastico, y nada conducentes para excitar la devocion, recogimiento y fervor de los fieles, ocasionandoles frecuentem ${ }^{\text {te }}$. notables distracciones, y disipaciones de espiritu, por lo que convendria que generalm ${ }^{\text {te }}$. se quitasen y desterrasen de los templos, los Violines, Flautas, y demas Instrumentos cuio profano uso es contrario a la circunspeccion y gravedad del Santuario. Hay un Colegio de Niños Musicos que se llaman Seises, los que se instruyen principalm ${ }^{\text {te }}$. en el Canto Eugeniano asi llamado de San Eugenio III. Arzobispo de Toledo, y para esto hay Maestro que llaman de Melodía con Racion y Capa de Coro. 


\section{Colegio de Infantes}

Otro Colegio hay con el titulo de Infantes, que asisten a los Divinos oficios; fundado por el Cardenal Siliceo antes del Concilio de Trento, y este egemplar sirvio de norma a los Padres Tridentinos: Sus Becas fueron quarenta, pero oy han quedado en veinte: Está a direccion de un Rector, queordinariamente es Racionero, y un Maestro de Gramatica. Cada año se nombran dos Canonigos, para que le visiten, y velen sobre su educacion.

\section{Capillas de la Iglesia. Ntra. Sra del Sagrario; San Eugenio y Sta. Leocadia}

Adornan y engrandecen esta mi Catedral treinta y nueve Capillas: La principal, fundada por el Arzobispo $\mathrm{D}^{\mathrm{n}}$. Bernardo de Rojas es de Nuestra Señora del Sagrario, cuia milagrosa y antiquisima Imagen tienen el Cabildo y Ciudad por Patrona, obrando la Divina Providencia por su mediacion grandes milagros. Su Fabrica es sumptuosa y de exquisitos Marmoles, Jaspes y Bronces dorados, todo de Orden Romano, teniendo para su adorno Alajas de muchisimo valor: A espaladas de esta capilla hay otra de semejante Arquitectura, en la que se hallan colocados los cuerpos del primer Arzobispo $S^{n}$. Eugenio y de Santa Leocadia, sus dos Patronos. Aqui están tambien insign[es] Reliquias, y otras muchas alhajas de exquisitos metales y piedras preciosas.

\section{Corpus Christi}

La Capilla de Corpus Christi, o Mozarabe, es Fundacion del Cardenal Ximenez de Cisneros, para conservar el antiguo oficio ecc ${ }^{\text {co }}$. de nuestra España; $\mathrm{Y}$ asi se canta en ella diariamente la Misa y oficio Divino, usandose del Misal, y Breviario Isidoriano, llamado Mozarabe: Se compone de nueve Capellanes.

\section{Reyes viejos}

La Capilla de Reyes viejos es Fundacion del Rey $\mathrm{D}^{\mathrm{n}}$.Sancho el IV: tiene quatro Capellanes, que en distintos dias del año cantan una Missa: es de Patronato y presentacion $R^{1}$.

\section{Reyes nuebos. Reynas $D^{a}$.Juana y $D^{a}$.Catalina}

La de Reyes nuevos, erigida por el Rey $\mathrm{D}^{\mathrm{n}}$. Enrique II tiene veinte y quatro Capellanes: Por la mañana celebran una Misa cantada (ademas de doscientas y ocho rezadas que tiene de carga anual cada capellan) y por la tarde cantan un Nocturno de difuntos. Las Reynas $\mathrm{D}^{\mathrm{a}}$.Juana y $\mathrm{D}^{\mathrm{a}}$.Catalina hicieron en la misma Capilla otra fundacion con Misa cantada, y otro Nocturno de difuntos: Sus Capellanes son cinco, los que con los veinte y quatro precedentes, pertenecen a la Presentacion $R^{1}$.

\section{San Pedro}

En la Capilla de san Pedro, que tiene doce Capellanos, y por Administrador un Canonigo que se muda todos los años, hay su Punto, y Misa diaria. Es la Parroquia de la Catedral, con dos Parrochos.

Instituciones eclesiásticas

Hispania Sacra 54 (2002) 
Importan los salarios en mrs.

a Ministros demi Dignidad .................................... 278.708 29

Reditos y Censos y otras cargas ........................... 281.202 ${ }^{3}$

Tributos, y otras asignaciones en especie de granos, un mil quatrocientas quarenta y nueve fanegas de Trigo, un mil quatrocientas treinta fanegas y quatro celemines de Cebada, una fanega quatro celemines y un quinto de Centeno, y once fanegas seis celemines y un quinto de Abena.

Estas Pensiones tan crecidas me impiden el ardiente deseo de socorrer a tantos Pueblos y necesidades, lo que causa en mi corazon notable daño y sentimiento, pues como los Diocesanos saben y ven con sus proprios ojos las grandes, y quantiosas rentas, que pertenecen al Prelado de esta Ig $^{\mathbf{a}}$., y por otra parte advierten, que no distribuye las limosnas correspondientes a ellas, no haciendose cargo, o ignorando muchos pobres las Pensiones con que se halla gravada la Mitra; oye sus clamores el Prelado, recurren a él en los años estériles, y es un dolor no poder estender la Caridad alo que en verdad se estienden las Rentas.

\section{Nueva ereccion de una gran Casa de Caridad}

Para ocurrir del modo posible a tan lamentables perjuicios, precaver otros maiores, y amparar alos verdaderos necesitados, y Pobres demi diocesis, me he aplicado con los maiores conatos y desvelos, sin perdonar dilijencia alguna, hasta quepor fin he conseguido la Fundacion de una gran Casa de Caridad, que acaba de establecerse en esta Ciudad de Toledo, habiendo contribuydo a este proyecto por mis encarecidas suplicas la Piedad de Nuestro Rey Catholico (Dios le guarde) con la donacion de un Real y Magnifico Edificio, digna havitacion en otro tiempo de sus Augusto[s] Predecesores: Goviernase esta Casa de Caridad por un Director, que es Canonigo de mi Iglesia, un Maiordomo, tesorero, Contador, y otros dependientes, que nombrala Junta de Direccion: Esta se compo[ne] del Prelado de la Santa Iglesia, de dos Canonigos como Diputados de mi Cabildo, del Rejidor decano de esta Ciudad, del Procurador Jurad[o] della, del Perionero y el Director de la Casa: todos conspiran a promover los augmentos de la noble virtud de la Caridad, progresos y subsistencia de un establecimiento notoriam ${ }^{\text {te }}$. util a mi pobre Rebaño, a el estado y a todo el Reyno.

Tampoco puedo premiar competentem ${ }^{\text {te }}$. a los Ministros demi Dignidad, pues el medio de honrarlos con Piezas ecc ${ }^{\text {cas }}$,, aunque le tuvieron mis Predecesores, oy estan muchas separadas de la Mitra, e incorporadas en la Corona, y agregadas a Colegios, y otras varias fundaciones: Por cuio motivo es tamb ${ }^{n}$. muy necesario disminuir las Pensiones, añadiendose alo dicho, ser tan grande el numero no solamente de Pobres de este mi Arzobispado, sino tambien de Conventos de Monjas, y Religiosos, quie mi antecesor el Cardenal Cordova se vio precisado a asignarles anualm ${ }^{\text {te }}$. mas de seis mil fanegas de trigo, fuera de las Limosnas que les dava en Dinero, por cuio socorro y el de los demas Pobres, no pagaba muchas Pensiones, las que se han satisfecho de su vacante como es bien notorio, e igualmente lo es que tenia para esttos fines mi referido Predecesor no solo las rentas de esta Mitra, sino tambien los grandes Estados del Condado de Theva, queposehia por su Casa. Posteriorm ${ }^{\text {te }}$. seme ha gravado con la Pension de la Orden del señor Carlos III y es necesario alo menos no inhavilitar al Prelado. 


\section{Parroquias}

Tiene esta Ciudad veinte y cinco Iglesias Parroquiales, diez y nueve Latinas, y las otras seis Mozaraves que conserban los derechos y Privilegios concedidos por los Reyes, y lex ${ }^{\mathrm{ma}}$. costumbre alos descendientes de los fieles queperseveraron durante la Dominacion de los Moros. Las mas Parroquias son pobres porla diminucion de Rentas, dimanada ya delainjuria de los tiempos, ya de la Gracia del Excusado.

Hay en las Parroquias de esta Ciudad, las de Arzobispado, y tambien en los Conventos varias fundaciones pias, Escuelas de Christo, Cofradias, y Hermandades; paratodo lo $\mathrm{q}^{1}$. hay aqui y en cada Partido un Visitador especial que las visita y hace llevar a efecto los Decretos del Synodo y del Prelado.

\section{Conventos}

Hay assi mismo en esta Ciudad quarenta Conventos, diez y siete de Religiosos y veinte y tres de Monjas de los que diez son de la obediencia y filiacion del Arzobispo; y los restantes de los Prelados Regulares: Los' mas son de tan corta Renta, que se ven precisados a mantenerse de Limosna.

\section{Convento de S. Bartolome en la Ciud. de Valladolid}

El Convento de San Bartolome de Religiosas Trinitarias enel Obispado y Ciudad de Valladolid distante de esta mas de quarenta leguas, por ciertas desavenencias que hubo sobre su govierno, se mando poner en secuestro, o deposito, en los Prelados de Toledo; en esta forma ha corrido y corre muchos años ha, pero convendria al servicio de Dios, y a la mas exacta disciplina, que removido el deposito, se encomendase el cuidado y govierno de este Convento al Obispo de Valladolid, quien como tan inmediato Pastor podria celar y advertir como testigo de vista, quanto fuese digno de reforma, y delamas puntual regular observancia.

\section{Colegio de Doncellas Nobles}

Tambien hay en esta Ciudad de Toledo un Colegio de Doncellas Nobles intitulado Nuestra Señora de los Remedios, y fundado por el Arzobispo Cardenal Siliceo para la educacion de Cien doncellas Nobles, Naturales de este Arzobispado. Estan governadas por el Arzobispo; un Administrador, y Rectora que se elije por trienios. El Administrador suele ser un Eclesiastico de relevantes prendas (siendolo oy el Obispo Auxiliar de esta Ciudad) y le elije el Rey a propuesta del Arzobispo: A las que quieren perseverar cas$\operatorname{tam}^{\mathrm{te}}$., se les permite; dando tambien parte de dote a las que resuelven tomar estado.

\section{Hospitales}

Hay asi mismo en esta Ciudad excelentes Hospitales. En el de los Niños Expositos fundado por el Cardenal Mendoza, se crian pasados de mil: Se administra por un Canonigo. Otro se intitula de San Juan Bautista, erigido por el Arzobispo $\mathrm{D}^{\mathrm{n}}$. Juan de Tavera, el que ademas de la Hospitalidad, y once Capellanes destinados para ella, tiene su Coro diario enel que se celebran los Divinos oficios, y se cantan las Horas Canoni- 
cas por sus Capellanes, y Administrador, que oy es Canonigo, nombrado por los Duques de Santisteban sus Patronos. El de la Visitacion, entendido vulgarm ${ }^{\text {te }}$. por el Nuncio, está establecido para curar Locos o Decapitados, y se administra por un Racionero nombrado por mi Cabildo. El que llaman del Rey para incurables y viejos: El de la Misericordia: El de San Pedro: Y otros.

\section{Tribunal de la Inquisicion. Universidad.}

Tiene tambien esta Ciudad Tribunal del Santo Oficio de la Inquisicion; y Unibersidad aprovada.

\section{Cumplimiento de Parrochos. Concursos.}

La Predicacion del Santo Evangelio y Palabra Divina es frecuente en esta Ciudad, y en las Parroquias del Arzobispado, por el ministerio de los Curas, que los hay muy doctos y egemplares pues se proveen por Concurso avierto. Este se hace ad mentem Concilii poniendo Edictos. Los Egercicios se reducen a media hora de leccion con puntos de veinte y quatro horas, y otra media de Argumentos; despues se hace un examen rigoroso de Moral por los synodales, que son Canonigos, y Prelados de las Religiones, presididos por el Arzobispo, o su Vicario general: Las Provisiones se hacen enlos mas benemeritos de Ciencia y probidad, dela que se procura tomar informes secretos.

\section{Obispos auxiliares}

Para conferir los sagrados orns. y Sacramento de la Confirmacion en este Arzobispado tan dilatado, y para servir de auxilio al Arzobispo, tiene este la necesidad de mantener dos Obispos Auxiliares, uno con residencia en esta Ciudad, y el otro en Madrid, a los que hace obligacion de dotarlos antes depedirselas Bullas.

\section{Gobierno del Arzobispado}

Hay en este Arzobispado dos Vicarios Generales, que residen el uno en esta Ciudad, y es regularmente Canonigo o Dignidad, y el otro en Alcalá de Henares.

\section{Madrid: Corte; Parroquias; Conventos}

En Madrid tengo un Vicario con su Tribunal correspondiente al despacho de sus negocios, y los de otros treinta y cuatro Pueblos: Para el cumplimiento de lo Eclesiastico, Memorias, Fundaciones, Cofradias y Parroquias de Madrid hay un Visitador: Trescientas treinta y cuatro son las Cofradias o Hermandades, y trece las Parroquias: A dos de ellas la de $\mathrm{S}^{\mathrm{n}}$. Sebastian, y de san Ginés, que son muy dilatadas, he puesto un Vicario perpetuo, residente en sus Anejos. El Visitador examina y reconoce todas las dhas. Parroquias y Fundaciones, a reserva de algunas que como Reales, estan vajo la inmediata Proteccion del Rey, y otras que se hallan en litigio sobre este particular.

Los Conventos de Religiosos de diferentes Ordenes son treinta y quatro, con otro mas extramuros, y veinte y quatro de Monjas, con dos Beaterios, delos que son diez de 
mi filiacion y obediencia; Para el buen govierno de estos tengo en Madrid un Superintendente o Visitador; y otro para los restantes del Arzobispado, con residencia en esta Ciudad, ambos de la literatura y buenas prendas que exige su Ministerio.

Hay un Oratorio de San Felipe Neri, y otro de Clerigos Misioneros llamado del Salvador, los que con otras Congregaciones de Eclesiasticos travajan bastante en la viña del Señor.

\section{Consejo de la Governacion}

Lo especial de mi Govierno es el Consejo que tengo en esta Ciudad de Toledo, y se llama dela Governacion: Su Jurisdiccion viene de inmemorial, y ordinariamente se compone de cinco Consejeros, delos que el Presidente y otro suelen ser Canonigos, y los restantes sugetos muy virtuosos y Doctos: En este Consejo se tratan los puntos de maior momento, y setraen a él las Apelaciones de los Obispados sufraganeos, y de los Vicarios Visitadores que hay en diferentes Partidos de este Arzobispado, los que conocen en primera instancia de todas las Causas que ocurren enlos Lugares de su respectivo distrito, a excepcion de las reservadas por Derecho.

\section{Alcazar}

En la Villa de Alcázar Partido del Priorato de San Juan de Gerusalem reside un Vicario y Visitador ordinario y Delegado Apostolico con las facultades necesarias para ejercer Jurisdiccion Diocesana y Apostolica Delegada en diez Villas del referido Territorio del Orden de $\mathrm{S}^{\mathrm{n}}$ Juan; todo con arreglo a la Concordia que se celebro entre las dos Dignidades Arzobispal de Toledo y Prioral de $\mathrm{S}^{\mathrm{n}}$ Juan, aprovada en forma especifica por la Santidad de Innocencio XII en el dia doce de Diciembre de mil seiscientos noventa y ocho y conforme a ella se despachan por el Gran Prior de San Juan las Colaciones de veinte Parroquias que tienen dhos. Pueblos en Religiosos del mismo Orden, y con ellas se presentan en mi Consejo de la Governacion para el examen, aprovacion ad curam animarum y licencia para su egercicio. Los Parrochos cumplen con sus obligaciones, castigando a los delinqüentes: Suele haver algunas controversias sobre extension de sus Privilegios, pero se cortan por la insinuada Concordia. Por hallarse uno de los referidos Pueblos cerca de Ciudad Real se le encarga el uso de la Jurisdiccion a su Vicario Visitador, por Decreto del Cardenal Portocarrero: El Pueblo de Villamiel es una Encomienda particular del mismo Orden, con separacion total, y sin mas intervencion del ordinario que para conceder la licencia ad curam animarum exercendam.

\section{Alcaraz}

En la Ciudad de Alcaraz tengo otro Vicario y Visitador con Tribunal y Ministros necesarios para lo que ocurre en dho. Pueblo, y otros veinte y ocho que comprende su Partido; En el que hay treinta y quatro Parroquias, inclusas dos Ayudas de Parroquia, y ocho Anejos: Tiene muchas Fundaciones pias, Capellanias y Hermandades, que se visitan por el referido Vicario Visitador, ocho Conventos de Religiosos, un Hospicio de los mismos, quatro Monasterios de Monjas, dos de ellos sugetos a la filiacion y obediencia del Arzobispo: Tambien hay treinta y dos Hermitas, trece Oratorios publicos y seis Hospitales. 


\section{Orán}

En la Plaza Ciudad de Orán, en Africa, reside otro Vicario y Visitador Diocesano pàra el conocimiento de las Causas que en ella se ofrecen, como enla villa y Plaza de Mazalquivir inmediata: Fue conquistada esta Ciudad por el Cardenal Arzobispo $D^{n}$. Fray Francisco Jimenez de Cisneros en diez y ocho de Mayo del año mil quinientos y ocho, y perdida en el demil setecientos y ocho. Se bolvio arecuperar casi milagrosamente en diez y seis de Julio demil setecientos treinta y dos. El mismo Vicario Visitador es Parrocho y Capellan maior de la tropa y gente de Guerra de aquellas Plazas, para lo que tambien se le da su nombram ${ }^{\text {to. }}$, y el Vicario general de los Egercitos sus facultades. La Iglesia Parroquial es de Real Patronato.

\section{Cazorla}

En la Villa de Cazorla hay otro Vicario Visitador que tambien es Juez Metropolitano de la Abadia de Baza y su territorio, por Concordia que hay entre el Obispo de Guadix y su Cabildo y el Prelado de Toledo, aprobada por la santidad de Paulo III en doce de Maio demil quinientos quarenta y quatro, y pasada por el Emperador Carlos $\mathrm{V}$ en su Provision expedida en diez y ocho de Agosto del mismo año.

\section{Villafranca del Puente}

En la Villa de Villafranca del Puente del Arzobispo reside otro Vicario Visitador, que al mismo tiempo es Parrocho de la Iglesia, la que tiene cinco Capellanes con la obligacion de asistir al Coro por mañana y tarde alos divinos oficios, y de celebrar diariamente tres Missas, una Combentual cantada pro Populo despues de tercia, otra al Alba por los Prelados difuntos de este Arzobispado, y la otra pro Benefactoribus: Tambien hay en dha. villa un Hospital para socorro de Peregrinos y Enfermos; Todas son fundaciones del Arzobispo de Toledo $\mathrm{D}^{\mathrm{n}}$. Pedro Tenorio.

\section{Huescar}

En la Ciudad de Huescar reside assi mismo un Vicario Visitador, quien tiene otros dos Pueblos en aquel Partido: La Cura havitual esta en el Arzobispo de Toledo, y en sunombre la actual en el Vicario, para cuio Egercicio nombra sus Tenientes.

\section{Ciudad Real}

En la Ciudad de Ciudad $\mathrm{R}^{1}$. reside otro Vicario Visitador con Tribunal formado, $\mathrm{y}$ Ministros necesarios para el egercicio de la Jurisdiccion Diocesana en ella y quarenta Pueblos de su Partido; En los que hay quarenta y cinco Parroquias con inclusion de siete Anejos; veinte y nueve Hospitales; Ciento setenta y nueve Cofradias y Congregaciones, y un largo numero de Hermitas, Positos Montes de Piedad, y otras Fundaciones: veinte y seis de los referidos Pueblos son dela orden de Calatraba. 


\section{Talavera}

En la villa de Talavera hay otro Vicario y Visitador con Tribunal correspondiente para el conocimiento de las Causas enlos Cincuenta y dos Pueblos a que se estiende el Territorio dela Vicaría, ademas de los del Arcedianato titular de dha. Villa, en los quales tiene prevencion con el Vicario general que reside en esta Ciudad.

\section{Iglesias Colegiatas}

Su Colegiata es una de las quatro que hay en este Arzobispado; Tiene quatro Dignidades, nueve Canonigos, y otro agregado al Tribunal del Santo oficio, ocho Racioneros, cinco Capellanes, y doce Musicos; En el ambito de la Ig ${ }^{\mathrm{a}}$. hay seis Capillas, sirviendo la una de Parroquia, y se nombra su cura de Almas por el Dean y Cavo ${ }^{\mathrm{d}}$. con las Aprovaciones necesarias de la Jurisdiccion Diocesana; Se visita esta Colegiata por mi Comison especial.

\section{Alcala de Hénares}

En la Ciudad de Alcala hay otra Iglesia Colegiata eregida por el Papa Sixto IV en el año mil quatrocientos setenta y siete, a solicitud del Arzobispo $\mathrm{D}^{\mathrm{n}}$. Alfonso de Carrillo; Y por el Cardenal Arzobispo Cisneros en el año de mil quinientos diez y nueve se obtubo Bula de Leon X para que se denominase Magistral, y desde este tiempo tiene cinco Dignidades, veinte y ocho Canonigos doctores en Sagrada Theologia, o Licenciados Canonistas, graduados en la Unibersidad que en la misma Ciudad fundó con facultades Apostolicas y $\mathbf{R}^{\mathbf{s}}$. el Carden ${ }^{1}$. Arzobispo Cisneros, o en las Unibersidades de Valladolid, Salamanca, Bolonia o la Sorbona: Un Personado Arcipreste de la Parroquial de Santa Maria de dha. Ciudad tiene silla en el coro de la referida Magistral, y puede juntarse con Canongia, pero no las demas Dignidades, que son incompatibles: Quince Raciones que se han de proveer en Maestros de Philosophia: Para sus Provisiones hay Concordia entre el Rey, mi Dignidad, y la Unibersidad desde el año mil quinientos cincuenta y tres: En la misma Ciudad reside un Vicario general con su Tribunal correspondiente.

\section{Pastrana}

En la Villa de Pastrana propria de los Duques de este titulo se fundó y erigió en Colegiata la Iglesia Parroquial $\mathrm{q}^{\mathrm{e}}$. alli havía, en virtud de Bula Apostolica de san Pio V en el año de mil quinientos ochenta y tres: tiene ocho Dignidades, doce Canonigos, doce Racioneros, diez y seis Capellanes, y catorce oficios amovibles para el mejor servicio de la Iglesia: todas las referidas Piezas Eclesiasticas sepresentan por el Duque de Pastrana, como unico Patrono, y sedan las Colaciones por los Arzobispos de Toledo, a excepcion del decanato cuia Colacion pertenece ala Silla Apostolica.

\section{Escalona}

La quarta y ultima Iglesia Colegiata de esta Arzobispado es la de la villa de Escalona del Patronato de los Duques de este titulo. Hay en ella siete Dignidades, doce 
Canonigos, doce Racioneros, doce Medios Racioneros, y otros tantos Capellanes. Se visita esta Colegiata por mi Dign ${ }^{\text {. }}$.

\section{Canales}

A mas delos referidos Vicarios Visitadores hay algunos otros Visitadores Ecclesiasticos en diferentes Partidos de este Arzobispado. Para el de Canales y Escalona se nombra uno, el que de dos en dos años hace la visita de todos los Pueblos de su Partido, que son setenta y cuatro, y en ellos Cincuenta y cinco Parroquias, y diez y nueve Anejos; Que todos se sirben por Curas proprios, y tenientes idoneos, cumpliendo con sus respectivas obligaciones del Ministerio Parroquial: Hay muchas Hermitas, Cofradias, Congregaciones, Memorias de Missas y otras obras pias.

\section{Zorita}

La Visita llamada de Zorita comprende la Parroquial de Pastrana, con otros sesenta y cinco Pueblos, en los que hay Cincuenta y dos Iglesias Parroquiales Matrices, y trece Anejos: Hay tambien un crecido numero de Memorias de Missas, cinco Hospitales, muchas Hermitas, Hermandades, Positos de Trigo Montes de Piedad, y otras fundaciones que se hacen cumplir exactam ${ }^{\text {te }}$. por el Visitador.

\section{Ocaña y Guardia}

Hay nombrado otro para visitar quarenta Pueblos del Partido de Ocaña y Guardia, donde se hallan quarenta y tres Parroquias inclusos quatro Anejos, y un competente numero de fundaciones de Capellanias, Hospitales, Cofradias, Positos y semejantes' destinos pios: Para evitar qualquiera descuido, o culpable omision se ponen en la visita Ecclesiastica las mas oportunas Providencias.

\section{Talamanca, Hita, Cogolludo y Uceda}

La Visita de Talamanca, Hita, Cogolludo y Uceda se estiende a Ciento veinte y tres Pueblos, que tienen Ciento veinte y nueve Parroquias, inclusos treinta y tres Anejos: Hay igualm ${ }^{\text {te }}$. un gran numero de Capellanias, Memorias de Missas, Hospitales, Hermitas, Positos y otras Piadosas Fundaciones.

\section{Rodillas y Montalvan}

Para el Partido de Rodillas y Montalvan, que comprende Cincuenta y un Pueblos, y en ellos Cinq ${ }^{\text {ta }}$. y cinco Parroquias, con inclusion de ocho Anejos hay nombrado otro Visitador Eclesiastico, que procura celar, y hacer que se cumplan todas las fundaciones de ese Partido, en el que tambien hay un Colegio para instruccion de Jovenes en la Latinidad.

\section{Yllescas}

La Visita de Yllescas tiene veinte Pueblos, y en ellos diez y nueve Parroquias, y dos Anejos; Tres Hospitales para curacion de enfermos, y quatro para acogimiento de 
Pobres Transeuntes, muchas fundaciones de Capellanias, $Y$ obras pias que se examinan y reconocen en las visitas eclesiasticas pidiendo razon de su cumplimiento, y dandose sobre ello las Providencias conducentes.

\section{Alcala y Guadalajara}

Hay nombrado otro Visitador para noventa y seis Pueblos, y en ellos Ciento y seis Parroquias del Partido de Alcalá, Guadalajara, y Alcolea de Tajo, donde son muchas las fundaciones y obras pias de insigne memoria, todas con destino al maior culto y obsequio de Dios, Bien Espiritual demi Rebaño, socorro de las Animas del Purgatorio, y egercicios de Piedad y Misericordia.

\section{Montes de Toledo y Puebla de Alcocer}

La Visita llamada de Montes de Toledo tiene por su demarcacion treinta Pueblos con otras tantas Parroquias, inclusos once Anejos. Hay siete Hospitales para curacion de Pobres enfermos; Dos Casas de Refugio para transeuntes; y un excesivo numero de Capellanias, Memorias de Misas, Positos Montes de Piedad para reparar Trigo a los Pobres Labradores, y otras obras pias.

En todos los Pueblos de las expresadas Visitas residen los proprios Parrochos, los mas seproveen por Concurso abierto en sus proprias Iglesias, y no se ausentan de ellas sin licencia correspondiente que se les da por tiempo moderado, y con arreglo a los Decretos Conciliares. En cada una de las Parroquias hay Libros separados para escrivir las Partidas de Bautismo, Confirmacion, Matrimonios, Y Mortuorios, y se ejecuta conforme a Constituciones Synodales de este Arzobispado. Tambien hay otros Libros $\mathrm{q}^{\mathrm{e}}$. compreenden todas las Fundaciones Piadosas; otros que explican los bienes de cada Iglesia, su estado, con las Cuentas que se toman en cada Visita de las Rentas, y su distribucion; Otros relativos alas Capellanias alli fundadas; Otros de Memorias de Legos con Cargas pias; Otros de Cofradias, Hospitales, Montes de Piedad, y semejantes; y todos se custodian en Archivo, y se hace de ellos el uso correspondiente en las Visitas. Los Parrochos cumplen con la explica ${ }^{\mathrm{n}}$. del Santo Evangelio y Doctrina Christiana, y setienen Conferencias Morales, y de Sagradas Ceremonias. Las Missas se aplican pro Populo en los Domingos, y Fiestas de precepto: Las Sacristías de todas las Parroquias de dhos. Pueblos con arreglo a los Decretos de Urbano VIII y Synodo de este Arzobispado tienen una Tabla conla descripcion del Cargo de Missas y Aniversarios de Fundaciones Piadosas para cuidar de su cumplimiento conforme a la voluntad de sus fundadores: Las Fabricas Materiales de dhas. Iglesias estan bien reparadas, y surtidas de ornamentos, Alajas, y vasos sagrados, para celebrar los santos Misterios y Funciones eclesiasticas, en lo que se convierten sus Rentas.

Todos los Visitadores embian razon ami Consejo de la Governacion de cuanto han actuado en sus respectibas visitas, dando cuenta al Prelado de lo que necesita de reformacion, y de la conducta, vida y costumbres delos Parrochos y sus Tenientes, y demás eclesiasticos. 


\section{Jurisdicciones temporales de la Dignidad Arzobispal}

A más delo quepertenece al Govierno espiritual tiene tambien el Arzobispo de Toledo el temporal y señorío de la villa de Talabera, con la Jurisdiccion de treinta Pueblos de su Distrito: El de Cazorla, y las Villas de su Adelantamiento; El de la Ciudad de Alcalá de Henares, y villas de Santorcaz, Villafranca del Puente, y Camarena: Pone en estos Pueblos el Arzobispo de Toledo Correxidores, Alcaldes maiores, y demás Ministros necesarios para la buena Administracion de Justicia; de todas sus determinaciones se apela y conoce en segunda instancia mi Consejo de la Governacion por Instrucc ${ }^{\text {es }}$., Cartas acordadas y lex ${ }^{\mathrm{ma}}$. costumbre.

\section{Privilegios de las Ordenes Militares}

Lo que turba el recto orden del govierno de este mi Arzobispado es el enorme abuso que de sus Privilegios hacen los de las Ordenes de Santiago, Calatraba, y exemptos de mi ordinaria: Santiago tiene un Vicario en Villanueba de los Infantes con veinte y un Pueblos, y en ellos veinte y tres Parroquias: otro en Villarrodrigo, a cuio cargo están su Parroquia, la de Jenave, y Torres de Albanchez, que son de la misma Orden: Algunos Parrochos de los referidos Pueblos son de presentacion del Rey como Gran Maestre, y con ella comparecen enmi Consejo de la Governacion, y precedido el Examen en Latinidad y Moral ad Curam animarum seles despacha el respectivo titulo en mi nombre: Al Vicario y Visitador de la Orn. de Santhiago sele da tambien (aunq ${ }^{\mathrm{e}}$. oy se resisten) el Titulo para el egercicio de Jurisdiccion en aquel Territorio.

\section{Abusos de los exemptos}

La Orden de Calatraba tiene veinte y un Pueblos y otras tantas Parroq ${ }^{\text {as }}$. en el Partido de Ciudad Real. Los Priores o Parrochos reciben la Provision y Colacion de dha. Orden, en virtud de sus Privilegios sin presentarse ami Jurisdiccion para Examen, ni otro Acto, de lo que resulta el no concurrir las mas veces en los provistos la suficiencia necesaria para el desempeño de su Ministerio Parroquial, como sobradamente lo tiene acreditado la misma experiencia; A este criminal descuido se añade otro de igual consideracion, en que tambien incurren los de la Orden de Santhiago, y es que casi todos los Parrochos de ambas Ordenes abandonan en muchas ocasiones sus obejas, y las fian a Mercenarios y Tenientes mas infelices, y menos idoneos que ellos, de suerte que con verdad se puede decir que tienen sus Curatos como si fueran Beneficios Simples, faltando a sus indispensables obligaciones, y ocasionando su desrreglada conducta y falta de pasto espiritual los imponderables daños que son consiguientes, siendo la mayor lastima el que yo no tenga arvitrio para remediarlos, pues como de Lugares Exemptos (aunque intra Dicecesim) si se quiere proceder contra ellos, u otros Clerigos de aquel Territorio, acuden inmediatamente a la Junta $A p p^{\text {ca }}$., adonde se llevan en fuerza de $R^{s}$. Provisiones qualesquiera Autos, que por los Ministros de mi Jurisdiccion se principian, haciendose de este modo ilusorias todas sus providencias, y no consiguiendose el Castigo y Enmienda de los Delinqüentes; $\mathrm{Y}$ aunq . por ser territorios de este Arzobispado, en el $\mathrm{q}^{\mathrm{e}}$. de immemorial se ha egercido la Jurisdiccion Diocesana y estar sujetos dhos. Parrochos Priores a la Visita y Corrección por los Ministros de mi Jurisdiccion en todo 
lo perteneciente a la Cura de Almas, y Administracion de Sacramentos, y pudiera usarse de ella, y de la Apostolica Delegada en quanto concierne al Culto Divino, frustran igualmente este medio por el insinuado recurso a la Junta Apostolica, donde logran Cedula $\mathrm{R}^{1}$. para la remision de Autos y suspension de todo procedimiento; $\mathrm{Y}$ esto sin embargo de las Egecutorias ganadas pormi Dignidad en los años de mil seiscientos quarenta y nueve, y mil seiscientos setenta y cinco por las que fue mantenida y amparada en la posesion, uso y egercicio de la Jurisdicc ${ }^{\mathrm{n}}$. ordinaria Diocesana en la Visita ecc $^{\text {ca }}$. y en el conocim ${ }^{\text {to }}$. y correccion de los excesos, que cometieren dhos. Priores Parrochos en el oficio de la Cura de Almas.

Llega a tal extremo su mucho orgullo, y poca subordinacion, que hasta sus mismos Vicarios Visitadores que reciven el Titulo de mi Dign ${ }^{\mathrm{d}}$. y juran guardar las Instrucciones, Cartas acordadas, y Synodales deste Arzobispado, tienen el atrevimiento de no hacer caso de mis mandatos, valiendose de sus Privilegios para la relajacion de la Disciplina ecc $^{\text {ca }}$., desprecio de mi Mitra, y vilipendio del Estado, por lo que convendria al servicio de Dios, Bien de sus Almas y puntual obediencia de todas las de mi Arzobispado, atajar tan graves perjuicios, y apartar de su vista el mal egemplo que ven y notan mis subditos en sus ConDiocesanos y Vecinos, por la demasiada extension, e irracional inteligencia de sus Privilegios; lo que justamente me ha empeñado a recurrir a nuestro Catolico Monarca, a fin de que se obserben las Concordias celebradas entre la Dignidad Arzobispal, y las Ordenes Militares, o que se forme un Reglamento o nueva Concordia capaz de cortar dudas, y abusos de los Exemptos.

\section{Excesivo num - de Conventos y sus abusos}

La multitud excesiva de Conventos de Religiosos es otra causa que pide remedio muy eficaz. Pues como son tantos, no tienen suficientes rentas para su congrua sustentacion, y se ven precisados a mantenerse de limosnas continuas y extraordinarias, dejando muchos con este pretesto el retiro de sus Claustros, y siendo bastante gravosos a los Lugares por donde andan vagando y pidiendo limosnas, viviendo algunos en lo exterior mas como seglares que como Religiosos: Estos, y otros inconvenientes tubieron presentes los Padres del Concilio de Trento quando tan santamente establecieron que las Comunidades Religiosas no recibiesen mas individuos de los que pudiesen mantener con sus rentas y Limosnas acostumbradas; pues de esta suerte les darian a sus Religiosos todo lo necesario, y, siguiendo el espíritu de sus Patriarcas, observarian exactamente la vida comun, que es la verdadera, y el medio mas eficaz de su reforma, porq. no tendrian tanto comercio con los seglares, para solicitar de ellos el alivio de sus necesidades Religiosas, guardarian mejor en los sagrados Claustros su primitiva disciplina, se animarian a la maior perfeccion, y procurarian entregarse mas a la oracion y al Estudio, sin atender a respetos humanos, sosteniendo las mas solidas opiniones, y no las mas anchas y laxas por agradar a las Gentes.

\section{Lugares despoblados}

Se han despoblado y extinguido muchas villas y Lugares de esta Diocesis en que havia Iglesias Parroquiales; de estas y sus Fabricas perciven los Racioneros de Toledo todas las Rentas, por Bula del Sumo Pontifice Nicolao V, a instancia de $\mathrm{D}^{\mathrm{n}}$. Alfonso 
Carrillo Arzobispo de esta santa Iglesia, quien sin duda no previo las disputas y funestas consecuencias que havia de ocasionar semejante Privilegio, y aunque el mismo Arzobispo declaró que fuese y se diese por Lugar despoblado el que no llegase a cinco Vecinos, no por eso calmaron los pleitos y dudas, ya sobre la interpretacion de este Decreto, y ya porque los Parrochos quando menos tacitamente conspiran a fomentar la solicitud de los Racioneros con el torcido fin de que, dandose por Rural su Curato, lo tienen como un Beneficio simple, y se libran de la residencia dejando el pasto espiritual de sus obejas al cuidado de un Mercenario, o Teniente, y a esto se sigue la acelerada ruina de los Pueblos, quedandose estos desiertos de todos sus Vecinos, que por el provecho de sus Almas procuran trasladarse a maiores Poblaciones, donde tengan proprio Pastor, y haya Iglesia Parroquial, porque la de su Despoblado se ba arruinando sin remedio, por aplicarse sus Rentas de Fabrica al Cuerpo de Racioneros de esta santa Iglesia, en virtud del referido Privileg ${ }^{\circ}$. que llaman de Despoblados.

Estos son $\mathrm{Ss}^{\mathrm{mo}}$. $\mathrm{P}^{\mathrm{e}}$. los principales y generales abusos, dignos a la verdad de ponerlos para su remedio en la alta comprension y acreditada Prudencia de V.B. de la que espero se dignará advertirme y enseñarme quanto deba practicar para el mejor acierto de un Govierno tan dilatado, y tan desigual a mis fuerzas; en lo que estas alcanzan procuro trabajar incesantemente para desempeñar las obligaciones de mi cargo, y en prendas del paternal amor que profeso a todos, y a cada uno de mis subditos: En esta atencion solo deseo la benevola Bendicion de B.V. y las saludables instrucciones de su santa sede, que me servirán de grande consuelo, como dictadas por la Cabeza de la Iglesia, a quien el Todo Poderoso guarde los felices largos años que la Christiandad ha menester, y nos conviene. Toledo y Junio 3 de 1776.

(Con letra de otra mano y firma autógrafa del arzobispo)

Santissimo Padre

Humildemente rendido a los Pies de V.B.

$$
\text { Fran }^{\text {co }} \text {. Arzobispo de Toledo }
$$

\subsection{Informe ${ }^{12}$ del arzobispo don Francisco Antonio Lorenzana. Año 1780}

$$
\text { Beatissime Pater. }
$$

Quod superioribus annis Beat ${ }^{\text {me }}$. Pater, postquam ad huius Archiepiscopalis Ecclesiæ regimen admotus sum, perficere curavi, et mei muneris memor, et Prædecessorum meorum exemplo ductus, ut totius Archidiœceseos plenam B.V. rationem exhiberem, id ipsum nunc pro temporum congruentia iterum faciendum suscipio; ut quando coram id mihi assequi non licet, saltem per litteras huius S. Metropolitanæ Ecclesiæ notitia ad B.V. pervenire possit, quam, tanquam Supremum Ecclesiæ Pastorem, omnium Ecclesiarum solicitudo premit.

\footnotetext{
12 ASV, Congregación del Concilio, Relationes Dioecesium, Toletana 805-B.
} 


\section{Civitas Toletana, eiusque stemma et S. Ecclesice}

Toletum Civitas Regia, et Imperialis appellata ab Alphonso VII et VIII Imperatoribus cognominatis, necnon ab Alphonso X Imperatore revera electo, licet non ab omnibus recognito; olim Regum Gothorum, post Maurorum vero expulsionem etiam Alphonsi VI Castellæ Regis, eiusque successorum Regia Sedes fuit. Stemmate Civitas utitur, Imperatore sedente, manu dextra nudum gladium, sinistra clavum tenente. S. Ecclesiæ Toletanæ stemma est Descensio B. V. Mariæ sacra indicentis veste S. Ildephonsum ob præclaram eius perpetuæ Virginitatis, atque ab omni labe inmunitatis defensionem adversus Helvidium et Pelagium, seu ejus sectatores.

\section{Toleti situs}

Sita Civitas est supra eminentem collem ad fluvium Tagum, qui eam circumfluit, in veteri Carpentana Provincia, hodie Castellæ novæ. Resident in ea Intendens Regio Ærario, et Gubernator Civitatis. Nobili ornatur Senatu, cæterisque publicis officiis, necnon S. Inquisitionis Tribunali.

\section{Limites Archiepiscopatus}

Archiepiscopatus limites adhærent ab Oriente Diœcesi Carthaginensi, et ultra eam amplectitur in ora Africana ad mare Mediterraneum Oranum Civitatem munitam, et Arcem de Mazalquivir in Argelitano Regno. Ab occasu Diœcesi Placentina, ab Aquilone Segoviensi, a meridie vero Cordubensi circumscribitur.

\section{Oppidorum et Parochiarum numerus}

Intra Diœecesim numerantur septingenta triginta duo oppida, et in eis octingentæ viginti tres Parœciæ.

\section{Episcopi suffraganei}

Diœeeses suffraganeas habet Seguntiam, Cordubam, Segoviam, Concham, Carthaginem, Xiennium, Oxomam, Vallisoletum, et Abbatiam de Baza in Diøcesi Accitana, seu de Guadix.

\section{Prcesulum toletanorum numerus}

Præsules Toletanos mecum ennumero centum et unum. Primus ex his hujus Ecclesiæ Fundator et Magister S. Eugenius, qui creditur a Discipulis Apostolorum ad Hispanias missus. Cæteri clarissimi virtute, litteris, et genere. Sex enim albo adscripti Sanctorum. Sex Regum Castellæ et Aragoniæ filii. S. R. Ecclesiæ Cardinales plurimi. Quidam Duces etiam exercitus quos inter eminent Egidius Carrillo de Albornoz qui ditiones temporales S.R. Ecclesiæ restituit, et expugnavit; de quo in Constit. I. Innoc. VI incipiente Cum onus, quam singillatim exponit Card. Petra, hæc verba reperiuntur "Attendentes quod tu potens opere et sermone, quem in magnis expertum, et arduis, probitate, et fidelitate probatum, gratiarum Dominus scientiæ magnitudine, industriæ claritate et maturitate 
consilii, morum elegantia, et aliis grandium virtutum titulus insignivit; in cuius affectu geritur, ut indubitanter tenemus, pacificare discordes, sedare fluctuationes, et turbines, justitiæ terminos colere, et errantes ad vitam rectam redducere veritatis. etc.".

Petrus Gonzalez Mendoza et Franciscus Ximenius Cisneros exemplum sequuti, Roderici Ximenez de Rada, qui de Hispanica scripsit Historia, etiamque adfuit Alphonso VIII in prœlio adversus Arabes obtento apud Navas de Tolosa, et Martini Lopez de Pisuerga, cuius ope, et consilio plurima contra Mauros patrata facinora.

\section{Fidei Mysteria}

Catholicæ fidei Misteria Diœcesis hæc fideliter retinet, nullusque in ea error sive communis, sive privatus reperitur. Supremum namque fidei tribunal et ecclesiastici Judices Ordinarii severe in eos animadvertunt, qui temere a fide vel tantillum discedant. Decreta insuper Ecumenicæ Synodi Tridentinæ ad amussim observantur.

\section{Archiepiscopatus tituli}

Castellæ Cancellarii maioris dignitas, quæe unum e præcipuis hujus sedis insignibus est, anno 1135 erecta fuit, eaque fere semper Prædecessoribus nostris conferri solebat; tandemque D. Petro Gonzalez de Mendoza Archipræsule, qui ab He[n]rico IV Rege Cancellarius nominatus fuerat, Archiepiscop[a]tui præfatum titulum Catholici Reges in perpetuum accensuere.

\section{Caxisice Profectura}

Caxisiæ præfecturam, eiusque Villarum, quam nostra [gen]tes vulgo appellant (el Adelantamiento maior de Cazorla) sedes nostra insuper habet; atque ideo donata ei fuit, quod a Mauri[s] illam præfatus Archiepiscopus D. Rodericus Ximenez Rada expugnavit. In his præterea, quæ ad spirituale regimen spect[ant] Madaurense Castrum, atque huic proxima Africana Castell[a] Catholicorum Regum Ferdinandi, et Elisabethæ temporib[us] a D. Francisco Ximenez de Cisneros bello obtenta, nostræ gubernationi spirituali subduntur; in tantique memoriam facinoris jus hoc; vel post ultimam expugnationem, in Archiepiscopali sede sartum, tectum remansit.

\section{Excellentia Dignitas}

Cum Philipus V Rex hanc ut pote Primatem sedem honore comppellationis a cæteris secerni peroptaret, eam, Excellentia, ut vulgo dici solet Regni Procerum, atque eorum tantum, qui a consiliis Status sunt, peculiari privilegio honoravit, quemadmodum liquet ex ejus Regio decreto nono Januarii anni 1722 emisso.

\section{Toletana Cathedralis Ecclesia}

Alma huius urbis Cathedralis Ecclesia, ut constans fert traditio, atque Sedes Apostolica peculiaris officii indulto comprobat, a Sacrosancta Virgine corporali descensione fuit decorata, dum Ildephonsum servum suum præclarum sacra superinduit veste ob egregium De Virginitate tractatum. 


\section{Ejusdem constructio}

Ædificium eam reddit cunctis spectabilem. Maurorum templum cum esset, vi primum Alphonsus VI suæ eam ditioni restituit, Christianorum Cathedralis effecta est, et S. Rex Ferdinandus templum, quod hodie dum cernitur inchoavit. Excellit tum architectura genere Gothico, tum amplitudine, ornatu atque Cappellis. Habet longitudinis quadringentos pedes, ducentos et amplius latitudinis. Ingens hoc templum in quinque naves precipuas divisum est, duabus aliis, quæ a latere Cappellarum sunt, non computatis. Duobus de nonaginta columnis innititur, atque septingentæ et quinquaginta lucem ei immitunt vitreæ fenestræ ad ignem depictæ. Admiranda ejus turris trecentos quinquaginta et novem pedes habet altitudinis, duodecim instructa cimbalis, quorum maius triginta quinque pedum circumductione, atque duodecim longitudine constat, ejusque pondus ad quadraginta fere millia librarum extenditur.

\section{Fabrica proventus}

Fabricæ proventuum curam gerunt Præsul, atque Canonicus Administer ab eo nominatus, qui ob eam causam Operarius appellatur. Intus Ecclesiam sua est officina cum Ministris ad rationes conficiendas necessariis, quorum supputationem Capitulum a Canonicis Visitatoribus quotannis examinari curat.

\section{Capitulum}

Canonicorum et Dignitatum cœtus virtute, litteris, atque natalium claritate est conspicuus: in ejus numerum plerumque ex aliis Ecclesiis accersiti cooptantur. Canonici autem numerum quadraginta non excedunt, et ex eis una Præbenda Sacro Inquisitionis Tribunali adscripta existit. Sunt præterea Dignitates quatuordecim. Portionarii quinquaginta, atqueCanonici, quos extravagantes vocant, decem. Quadraginta quatuor ibidem sunt Cappellani, qui de numero dicuntur, quibus novem alii nonnullarum Fundationum accedunt. Præfati omnes stirpis honestatem suæ bono in lumine collocare debent, quemadmodum Paulus III et IV Summi Pontifices diplomatibus suis ad Cardinalis Joannis Martinez Silicei preces emissis præscripsere. Triginta novem Canonicis celebratio, cantusque missarum incumbit: Choro adsistere, atque canonicas ibidem horas recitare tenentur. Unde Canonicatus hosce Presbiteralem ordinem annexum habere censetur. Evangelii atque Epistolarum cantus a Portionariis expletur. Ex hactenus recensitis Canonicis quinque officio funguntur; a Concionibus videlicet unus $\mathrm{Ca}$ nonicus, alter a confesionibus, theologalis alter, tandemque Doctoralis munere alii duo insigniti: in quorum omnium electione Tridentini decreta ad unguem observantur.

\section{Divinorum officiorum celebratio}

Tanta in Divinis officiis celebrandis est solemnitas, ut pia illa sit admiranda contentio, qua munia unusquisque sua adimplere diu, noctuque satagit. Eam quoque in rem cantus ecclesiastici apprime docti quamplurimi sunt Psalmistæ, quorum uni diurnum chorum, nocturnum vero Matutinorum ad galli cantum peragi solitum, moderantur alii. Musicorum est omnibus numeris absolutus cœtus: multa præterea sunt Musi- 
ces instrumenta: eorum aliqua ecclesiasticis concentibus minus congrua, devotionem fervoremque fidelium neutiquam juvant; quinimo distractioni et animi vagationi sæpe sæpius occasionem præbent. Unde tibiam, mirem fidim, aliaque id genus suffitus, et chordarum omnino templo Dei tolli, ac penitus eliminari opporteret; eorum enim ut plurimum prophanus usus Sanctuarii dedecet honorem, et gravitatem. Neque ad id assequendum sola Prælati sufficit auctoritas, nisi Apostolica et Regia fulciatur protectione.

\section{Collegium vulgo de Seises. Eugenianus seu Melodicus cantus}

Collegium præterea puerorum est, qui Hispano idiomate de Seises nuncupatur, atque præcipuam in Eugeniano cantu a S. Eugenio III toletano Antistite, ut fertur, composito sive correcto; operam et studium navant. Est eorum Magister, quem Melodiæ appelant, Portionarius.

\section{Infantium Collegium}

Collegium alterum Infantium vulgo dicitur, quorum munus est Divinis interesse Officiis. Ante Tridentini tempora a Cardinali Joanne Martinez Siliceo erectum fuit; placuisse hanc institutionem tridentinis Patribus, eamque perlaudasse pro comperto habemus tantum hodie dum viginti sunt Colegæ, cum ante hac quadraginta extiterint. Illorum cura Rectori, qui portionarius ut plurimum est, atque Gramatices Præceptori a Capitulo meæ Cathedralis demandatur. Duo quotannis Canonici nominari solent, ut illud invisant, puerorumque educationi invigilent: mihique a S.Congregatione est injunctum hoc Collegium ad formam Tridentini reducere; sed non est perfacile jus Capituli inmutare; curabo tamen jussa, in quantum valeam adimplere.

\section{Cathedralis Ecclesice Cappellae}

Ecclesiam mirum in modum ornant, magnificamque reddunt novem et triginta Cappellæ, quarum præcipua a Cardinali D. Bernardo Sandoval et Roxas constructa fuit, atque B. Virgini titulo Sacrarii dicata. Imaginem hanc antiquitate et miraculis celebrem Capitulum et urbs in sui Patronam adscivere, ejusque intercessione Dei providentia mirabilia sæpissime operata est. Ædificatio ejus magnifica marmore, jaspide, æreque deaurato, ordine composito, Dorico videlicet et Corinthio constat, ejusque ornatui plurima sunt summi pretii suppellectilia. Ad hujus posteriora Capellæ altera similis omnino architecturæ reperitur. Eugenii et Leocadiæ Patronorum corpora collocata illic fuerunt, necnon plurimæ aliorum Sanctorum Reliquiæ auro gemmisque ornatæ; de hisque officium proprium recitatur.

\section{Corporis Christi Cappella, seu Mozarabica}

Cappella Corporis Christi, seu Mozarabica a Cardinali de Cisneros fuit reparata, ne vetus Hispaniensis Ecclesiæ officium et memoria nostratum penitus excideret. In ea etenim Divinum officium, ac Missa juxta ritum Gothicum sive Isidorianum singulis diebus celebratur, et a novem Cappellanis munus totum perficitur. 


\section{Cappella Regum veterum}

Regum veterum denominata Regia Cappella a Sanctio IV fuit erecta: ei adsistunt quatuor Cappellani qui certis anni diebus tenentur Missam pro Regibus canere: Patronatu Regio gaudet, et Cappellani a Rege nominantur.

\section{Regum novorum Cappella}

Veterum Regum nomine Sanctios, et Alphonsos denominamus: eosque tempore subsequentes Henricos et Joannes novos apellamus. Cappella igitur præfata ab Henrico II erecta viginti quatuor habet Cappellanos, quibus singulatim onus celebrationis ducentarum Missarum injunctum est, et præterea tenentur singulis diebus mane Missam solemniter celebrare et vespere nocturnum canere defunctorum. Eidemmet Cappellæ aliam adjunxerunt Reginæ Joanna et Catharina cum onere Missæ solemnis et Vigiliæ defunctorum.

\section{Cappella Parochialis S. Petri}

Cum una ex Parochialibus Toletanæ Civitatis intra Matricem sita esset, et Sanctius de Roxas Archiepiscopus Toletanus strictiori, quam decebat, loco vidisset, in ampliorem transtulit: simulque Cappellanum maiorem Canonicum et alios duodecim Cappellanos minores, quibus unoquoque die Missæ solemnis celebrationis et Vigiliæ defunctorum onus fuit injunctum, instituit, et Sacramentorum administrationi duo Parochi eliguntur, unus per concursum, alter per nominationem Capituli Ecclesiæ Cathedralis.

\section{Doctorum Cappella}

Cappellæ Imaginis B. Virginis del Sagrario proxima est alia ab Archiepiscopo Bernardo Sandoval et Roxas erecta ea lege ut septem Cappellani Doctoratus, aut Licentiatus gradu essent decorati.

Alice Cappella minores

Aliæ sunt insuper Capellæ Gothicæ Architecturæ in quibus per anni curriculum tum Missæ, tum vesperæ, tum defunctorum vigiliæ decantantur.

Missarum numerus, quæ singulis annis in hac S. Ecclesia celebrantur ascendit ad viginti et tria millia præter Missas privatas, quæ sponte celebrantur; et fere unoquoque die centum numerum explent.

Capitulum Ecclesiæ Cathedralis statuta et constitutiones ad amussim observat, necnon laudabiles consuetudines, quas ab antiquo retinet. Portionarii et Cappellani suis etiam reguntur constitutionibus; et unumquodque horum corpus suam retinet in spiritualibus fraternitatem, et in temporalibus segregatum regimen.

Dignitatis Archiepiscopalis proventus gravati sunt onere sequentium pensionum in favorem communitatum, et personarum, quas infra nominabimus. 


\section{Pensiones annuce}

Serenissimo Infanti D. Ludovico annuatim Bullis Apostolicis concesa est in ejus favorem quantitas nongentorum quadraginta sex millium, et centum et septem regalium monetæ Hispaniæ.

Regio Monasterio Escurialensi ordinis S. Hieronimi octoginta tria millia, et sexcenta regalia.

Fabricæ Parochialis S. Justi Matritensis quadraginta quatuor millia.

Regio Monasterio Monialium Discalceatarum S. Francisci Matritensi quatuor millia et quadringenta.

Congregationi Oratorii Salvatoris Matritensi decem et duo millia.

D.D. Patriarchæ Indiarum Regioque Procappellano maiori triginta tria millia.

D. Josepho Pacheco Velarde tria millia et tricenta.

Orphanotrophio toletano mille.

Regio Ordini Caroli III quadraginta quatuor millia.

Gratia Subsidii solvit annuatim sexaginta millia sexcenta et viginti tria.

Gratia Domus Escusatee solvit annuatim ducenta septuaginta tria millia, sexcenta et octoginta.

Episcopo Auxiliari Matriti residenti triginta et unum millia et sexcenta.

Episcopo Auxiliari Toleti residenti novem millia et sexcenta.

Quæ omnia summam conficiunt unius millionis, quingentorum quinquaginta duo millium, quadringentorum et decem regalium.

Deinde stipendia, quæ quotannis solvuntur judicibus et reliquis Ministris qui non Personæ sed officio deserviunt, videlicet Vicariis, Visitatoribus, Iudicis et Notariis hujus Dignitatis et Archiepiscopatus æquant summam ducentorum triginta quinque millium, trecentorum et octo regalium.

Reditus censuarii, et alia onera, quæ numerata pecunia quotannis persolvit Dignitas, æquant summam ducentorum et duo millium, octingentorum et octo regalium.

Quæ duæ summæ. pensionibus præcedentibus adjunctæ æquant unum millionem nongenta et nonaginta millia, quingenta et viginti sex, ut apparet.

Præter hæc persolvuntur a Dignitate Archiepiscopali tributa et assignationes quotannis in specie tritici mille tercenti octoginta septem modii (vulgo fanegas).

Insuper in specie hordei mille quingenti nonaginta novem modii.

Quorum omnium pretium moderatum conficit summam sexaginta et unius milium, centum et triginta et octo regalium.

Quæ summa reliquis superioribus annumerata conficit, ut apparet, summam duorum millionum, quingentorum et unius millium, sexcentorum sexaginta quatuor regalium.

Hæc ipsa recensitarum pensionum enormis summa me præpedit quominus indulgere possim ardente desiderio tot, tantisque Populorum necessitatibus subveniendi. Quod 
quidem incredibile dictu est, quantum me excruciet, quamque acerbo dolore cor meum scindat: Cum enim fideles non lateat (quoniam oculi eorum huius rei testes sunt) uberrimos et copiosissimos proventus ad hujus Ecclesiæ Præsulem pervenire, nec videant aliunde eleemosinas effusissimas fieri, quæ reditibus respondeant, non animadvertentes, vel ignorantes innumeras pensiones, quibus ultra modum gravatur; frequenter accidit, ut Pastor dolens infirmas oves tristes gemitus emitere audiat, et cum summo animi mœrore in dificilioribus, et calamitosissimis temporibus annonæ penuria ad se confugere videat, quin valeat caritatis, et misericordiæ sitim exaturare, nec ea exequi, ad quæ pingues sane reditus, si integri spectentur, abunde sufficere possent. Quæ omnia non eo animo B.V. expono, ut aliquid de eis in præsentiarum imminui vel detrahi velim, sed ut in posterum novis pensionibus non gravetur.

\section{Ecclesice Parochiales}

Hujus Civitatis Ecclesiæ Parochiales sunt 25 ex quibus 19 sunt Latinæ, sex reliquæ ritu utuntur Gothico, seu Muzarabico, atque apud se retinent jura et privilegia a Regibus olim concessa ac longa consuetudine continuata in favorem eorum fidelium, quorum maiores sub Sarracenorum dominatione fidem Catholicam constanter tenuisse comprobatur.

In prædictis Civitatis Parœciis, sicut in reliquis totius, qui late patet Archiepiscopatus, et in Conventualibus etiam Ecclesiis quamplurimæ sunt piæ fundationes, sodalitates atque confraternitates, ad quas invisendas Visitatores varii, pro suo unusquisque districtu, deputantur: qui omnes curant ut Synodalia decreta, et Ordinarii statuta diligenter observentur.

\section{Monasteria Virorum et Mulierum}

Sunt etiam in hac Civitate Conventus 40. Fratrum sunt 17. Monialium 23. Ex quibus 10 nostræ spirituali jurisdictioni ordinariæ subditi sunt; reliqui suis propriis Prælatis Regularibus.

\section{Puellarum Collegium}

Aliud est præterea Toleti Collegium Virginum Nobilium Dominæ nostræ vulgo de los Remedios; illud fundavit Em ${ }^{\text {mus }}$. Cardin. Siliceus hujus Ecclesiæ Archiepiscopus eo fine ut centum puellæ Nobiles ibi honeste et commode educarentur. Rector illarum est Archiepiscopus, deinde Economus, et Rectrix, quæ ex ipsis Collegis tertio quoque anno eligitur. Economus frequenter est sacerdos omni virtutum et ornamentorum genere maxime commendatus; eligitur a Catholico Rege ad consultationem Archiepiscopi. Illud vero minime silentio prætereundum est, puellas illas, quæ semel ingressæ inibi ægere constituunt, non amplius ad egrediendum urgeri; quibus autem placet statum conjugalem amplecti, eis aliqua dotis pars ab ipso Collegio donatur.

\section{Orphanotrophium}

Insuper Card. Petrus de Mendoza insigne Nosocomium et Orphanotrophium erexit in hac Civitate; in eo etenim mille et ultra expositi Infantes aluntur. Capitulo mex 
Ecclesiæ incumbit administratio redituum, et ad ejus regimen quotannus nominat vel reeligit non ultra triennium Canonicum Rectorem.

\section{Nosocomia et Xenodochia}

Extra mœnia Civitatis aliud præterea fundavit Xenodochium Card. Joannes de Tavera Præsul hujus Ecclesiæ, Patronosque nominavit Duces de Santiesteban, a quibus eligitur administrator et præsentantur undecim Cappellani cum onere inserviendi infirmis, et canendi quotidie horas canonicas.

Amentibus aliud Hospitium, Visitationis nuncupatum, erex[it] Canonicus Joannes de Vergara, vir latinis, græcis, hæbraicis et caldaicis litteris eruditus, ob ejus summam operam, quam cum aliis in Biblia Polyglota jussu Card. Ximenii de Cisneros impendit, summis laudibus a sui sæculi scriptoribus collaudatu[s]. Curam hujus domus gerit administrator Portionarius S. Ecclesix Cathedralis a Canonicorum Capitulo nominatus.

Præter ea erecta sunt in hac Civitate alia Hospitia, Berphotrophia: senibus unum valetudinariis, et insanabili morbo laborantibus, Regis nuncupatum: aliud Xenodochium nomine S.Petri peregrinis,' et denique alia minora Clericis pauperibus, et quarundam Parochiarum et sodalitatum infirmis.

\section{Universitas}

Decoratur Civitas Universitate, seu Schola publica, cum Pontificiis Diplomatibus, tum Regiis fulcita, et approbata seculo XV necnon S. Inquisitionis officio, quod a Civitate Conchensi Toletum fuit translatum tempore Caroli V Imperatoris.

\section{Parochorum electio et munus}

Verbi Divini prædicatio assidue resonat in omni Ecclesia Parochiali, præcipue diebus festis, in quibus Parochi fideles suos edocent mysteria fidei, et evangelicis incumbunt præceptis, cum sint enim Sacræ Theologiæ, aut jurisprudentiæ Canonicæ scientia præditi, id munus cumulate adimplent. Seliguntur namque ad officium Parochorum prævio examine cum in prædictis facultatibus, tum in Theologia morali. Et ut omnes digniores compareant, evocantur oppositores per edicta, quæ affiguntur non solum in hac Diœecesi, sed etiam in Universitatibus maioribus hujusce Regni, et finito termino coram Examinatoribus Synodalibus, præside Archiepiscopo, seu ejus Vicario Generali, lectionem per spatium dimidiæ horæ faciunt, postea conclusionem, quæ eis sorte contingit, defendunt, et denique scrutinium districte fit eorum idoneitatis in materiis moralibus.

\section{Episcopi Auxiliares}

Archiepiscopus tenetur duos Episcopos Auxiliares a Sede Apostolica confirmatos suis expensis, competentique dote sustinere, unum Matriti, alium Toleti, ne ullo tempore desit qui Matriti,Toleti, aliisve in partibus huius Diœcesis sacramenta Ordinis, Confirmationis, Altarium Consecrationes, aliaque munia Episcopalia exercere valeant, vivente Archiepiscopo, sive sede vacante cum licentia Capituli. 


\section{Vicarii Generales, et Matritensis}

Necnon residet Toleti unus Viccarius Generalis, e gremio, ut solet, Capituli, et alius Compluti. Matriti etiam resident Viccarius cum Tribunali, ut inibi incumbat negoti[a] Matriti, et aliorum locorum huic proximorum, et Visitator generalis operum piorum, Parochiarum et Confraternitatum. Harum enumerantur tercentæ et triginta quatuor, et ultra, Parochiarum tredecim, et duæ Viccariæ ecclesiasticæ Collativæ cum aliis Parochiarum auxiliaribus. Visitator igitur Ecclesiasticus invigilat executio operum piorum, et visitat Parochias principales, et accesorias, Eremitoria, aliaque pia loca nisi sint sub inmediata Regis protectione.

\section{Domus Religiosa Matritenses}

Intra muros Matriti sita sunt triginta quatuor Monasteria Religiosorum virorum diversorum ordinum, unum etiam extra muros; Mulierum ennumerantur viginti quatuor, ex quibus duodecim hodie meæ subsunt jurisdictioni: ulterius sunt duo Beateria, et Puellarum Nobilium Asceteria tum patronatus Regii, tum Optimatum.

Ut facilius possit Præsul Monasteria Monialium gubernare, residet Matriti Superintendens, seu Visitator Monialium, et alius Toleti, ut in plurimum Canonicus, qui invigilat Monasteriis extra Matritum consistentibus, et Præsulem consulit in negotiis gravioribus ad Moniales spectantibus.

\section{Oratoria}

Erecta sunt Matriti Oratoria S.Philipi Nerii et S.Salvatoris, aliaque Clericorum secularium, et in eis Catechismum fideles edocent, et alia pia opera caritatis et misericordiæ exercentur.

\section{Tribunal Gubernationis}

Cum in hac Diøcesi etiam a primis temporibus plures Archiepiscopi fuerint sive ex propagine Regia, sive assiduo Regibus Catholicis in Status consilio, aliisve publicis muneribus inservierint et per se ipsos decernere præpediti, absque hominum memoria ab ipso seculo undecimo, in quo Toletum fuit a Catholicis expugnatum, ussi sunt Archiepiscopi consilio quinque, aut sex virorum in jurisprudentia optime meritorum partim Canonicoruum Toletanorum, partim aliorum, qui in diversis officiis Viccariorum aut Visitatorum sunt experti, et immemorabili consuetudine exercent jurisdictionem Archiepiscopalem sub titulo Consilii Gubernationis Archidioeceseos in omnibus, quæ de jure non competunt Viccariis generalibus, seu particularium locorum Viccariis, Visitatoribus, et ipsi Episcopo sunt reservata; et appellationis recursu cognoscunt in causis appellationis factæ ab Episcopis suffraganeis, sive ab ipsismet Viccariis hujus Diœceseos.

Hoc tribunal maxime extollitur a cunctis jurisperitis, qui de eo tractarunt: et ut Sanctitati Vestræ planum fiat, sequentes evincunt rationes. I ${ }^{\text {a }}$. Ne si, ut assolet, Regius Infans in commendam, seu aliquis de genere Optimatum sedem Toletanum obtineat, Diœcesis hæc careat solito ordine, gubernio, consilio, et recta justitiæ administratione, tam super quærelas Viccariorum, quam super omnes, qui rationum computationibus, et 
decimarum administrationi incumbunt. II ${ }^{\mathrm{e}}$. Ut magis resplendeat justitiæ administratio, nam si in aliis non tam vastis Diœecesibus Metropolitanum unus sufficit Viccarius Generalis ad judicandum in causis suffraganeorum; Toleti sex Jurisperiti adunantur, ut in similibus causis decernant, et ubi sint plurium consilia, ibi sit salus. III a. Maiores persæpe causæ agitantur in hac Diœcesi quam in aliis, cum propter Aulicorum Dignitatem, tum propter pericula, quæ ex inordinata, et præcipiti decisione oriri possent: unusque aut duo Viccarii generales seorsim degentes non tam maturo judicio damna prævidere, et remedia apponere possent. Denique illa aliqualis adumbrata species Primatus sedis Toletanæ cernitur in hoc Gubernationis Consilio, sicut in maioribus Ecclesiis Galliarum præter Viccarium generalem est etiam Arelati, Lugduni, et alibi magnus Viccarius aliorum judicum, Superintendens et superior in his quæ sunt Episcopis reservata, et ut gravamina a Viccariis illata cito reparet. Hæc omnia non in cassum adduco; non enim latet Sedem Apostolicam quanto honore, quamque speciali favore Cathedra Romana sit prosequuta Ecclesiam Toletanam, eius dilectissimam filiam nuncupando: nec Barbarorum illuvies potuit eam faciem, et dignitatem obscurare; quam habuit pro comperto a temporibus Gothorum; sin minus a Concilio Toletano XIII in quo Primatus Toletanus ab omnibus Patribus fuit conclamatus.

\section{Viccarius de Alcazar}

In villa de Castro S. Joannis (vulgo Alcazar de S. Juan) residet Viccarius et Visitator cum assignatione territorii, et auctoritate Delegati Apostolici, ut in decem oppidis præfati territorii magni Prioratus Ordinis S.Joannis Hierosolimitani exerceat jurisdictionem ordinariam et Delegatam Apostolicam juxta concordata inter nominatum magnum Priorem, et Archiepiscopum Toletanum approbata a S. Pontifice Innoc. XII die duodecima Decembris anni 1698 et secundum eorum tenorem Magnus Prior S.Joannis Hierosolimitani confert Beneficia viginti Parochiarum Religiosis ejusdem ordinis, qui obtenta præfata collatione tenentur se sistere ante Archiepiscopum, seu ejusdem a Consiliis judices, ut prævio examine approbentur ad curam animarum, et hanc possint exercere.

Inter Dignitates Prioralem et Archiepiscopalem quædam exoriuntur controversiæ, præcipueque intendit Archiepiscopus ne Magni Prioris Ministri limites Concordiæ a Sede Apostolica in forma specifica confirmatæ transilire audeant. Una dumtaxat Commenda Oppidi de Villamiel ejus Ordinis omnino segregata a jurisdictione ordinaria existit; quim ad hanc Parochus recurrat, nisi ad obtinendam licentiam exercendi curam animarum.

\section{Viccarius de Alcaraz}

In Civitate de Alcaraz residet alius Viccarius, et Visitator, inibique erectum habet tribunal cum Notariis et Ministris, ut tam in præfata Civitate, quam in viginti et octo oppidis sui territorii jurisdictionem exerceat, curamque gerat triginta et quatuor Parochiarum, octo Populorum annexorum præfatis Parochiis. Simul visitat opera pia, confraternitates et cappellanias. In præfato territorio enumerantur octo Monasteria diversi Ordinis Religiosorum, et unum Hospitium eorumdem: quatuor Monialium Monasteria, quorum duo subsunt jurisdictioni Archiepiscopi. Denique sunt erecta triginta duo Eremitoria, tredecim Oratoria publica et sex pauperum Xenodochia; et Nosocomia. 


\section{Viccarius Orani}

In Civitate Oranensi Præsidio in Africa adversus Mauros munitissimo residet Viccarius et Visitator Diœcesanus, qui simul est Parochus, et Cappellanus maior Militiæ tam præfatæ Civitati, quam castris eidem adhærentibus inserviendis. Et cum Ecclesia Parochialis sit Regii Patronatus, obtinet Viccarius approbationem Regiam nominationis ab Archiepiscopo factæ; et ut tuto exerceat jurisdictionem super Cappellanos Exercitus ibi degentes simul obtinet ad omnem tollendam controversiam a Viccario Generali Exercitus suam facultatem. Hæc Civitas, et Castra eidem proxima expugnata propriis expensis a magno Card. Francisco Ximenez de Cisneros die decima octava Maii anni millessimi quingentessimi octavi, rursus in Maurorum potestatem devenerunt anno millessimo septingentessimo octavo, et denique armis invicti Philipi V fuit recuperata die decima sexta Julii anni millessimi septingentessimi trigessimi secundi.

\section{Viccarius de Cazorla}

In villa de Cazorla residet alius Viccarius Visitator qui simul est judex Metropolitanus Abbatiæ de Baza, et ejus territorii, juxta Concordata inter Episcopum Guadixensem, ejusque Capitulum, et Archiepiscopum Toletanum confirmata a S. Pontifice Paulo III die duodecima Maii anni MDXLIV et a Carolo V Regia schedula die 18 Augusti ejusdem anni roborata.

\section{Viccarius de Villafranca}

In villa franca quam appellant Pontis Archiepiscopi eo quod Præsul D. Petrus Tenorius suis expensis supra flumen Tagum ibi pontem amplissimum construxit, residet alius Viccarius, et Visitator, simul et Parochus Ecclesiæ Parochialis, in qua quinque Cappellani quotidie horas canonicas canunt in choro, eisque incumbit tres missas unoquoque die celebrare; unam tempore irradiantis Auroræ pro Præsulibus Toletanis, et aliam pro benefactoribus, et missam conventualem post tertiam pro Populo canere tenentur. Parochus iuxta S. Concilii Tridentini decreta Deo ofert sacrificium pro Populo. Præfatus Archiepiscopus Petrus Tenorius simul erexit in prædicta villa Xenodochium, et munificentissime dotavit.

\section{Viccarius de Huescar}

In Civitate de Huescar residet alius Viccarius, et Visitator, sub cujus jurisdictione duo alia oppida comprehenduntur. Archiepiscopus Toletanus habitu est, et nominatur Parochus præfatæ Civitatis, et ejus nomine Viccarius una cum duobus coadjutoribus actu exercet curam animarum.

\section{Viccarius Civitatis Regice}

In Civitate Regia (vulgo Ciudad Real) residet Alius Viccarius Visitator cum Tribunali, Notariis, et Ministris necessariis ad jurisdictionem Dioecesanam exercendam tam in præfata Civitate, quam in quadraginta oppidis sui territorii, in quo enumerantur quadraginta quinque Parochiæ: viginti et novem Nosocomia; centum septuaginta no- 
vem confraternitates; plura Eremitoria, aliaque opera pia. In cuius Viccarii districtu viginti sex oppida attinent ad Militarem Ordinem Calatravensem; sed iuxta Concordiam initam cum hoc Equestri Ordine a Sede Apostolica confirmatam, jurisdictio ordinaria Diøcesana supra Parochias, earumque Rectores in officio tantum Parochiali illæsa debet remanere, licet Religiosorum personæ in aliis subditi sint Superioribus sui Ordinis.

\section{Viccarius de Talavera}

In villa de Talavera alius residet Viccarius et Visitator cum Tribunali et Ministris ad id necessariis ad causarum cognitionem; et in ejus districtu ennumerantur quinquaginta et duo oppida.

\section{Collegiales Ecclesice Talavera}

Rudericus Ximenius de Rada Archiepiscopus Toletanus, qui una cum Rege Alphonso VIII prœlio a nostris apud Navas de Tolosa gesto adfuit, et de rebus Hispaniæ scripsit, insignem Ecclesiam Collegialem in præfata villa de Talavera erexit: in ea quatuor Dignitates, et decem Canonicatus, ex queis unus S. Inquisitionis officio est aggregatus; octo Portiones, et duodecim Ministri Musicæ ennumerantur. Intra Ecclesiæ ambitum sex sitæ sunt Cappellae, ex quibus una deservit administrationi Sacramentorum, et curæ Parochialis; ad quam Decanus, et Capitulum nominant personam idoneam cum approbatione jurisdictionis ordinariæ. Archiepiscopus per se, vel alius cum ejus speciali delegatione visitat Ecclesiam Collegialem.

\section{Collegiales Ecclesice Complutum}

In Civitate Complutensi alia est Ecclesia Collegialis erecta a S. Pontifice Sixto IV anno 1477 ad instantiam Archiepiscopi Alphonsi de Carrillo; postea Card. Ximenius de Cisneros anno 1519 impetravit a S.Pontifice Leone X ut præfata Ecclesia denominaretur Magistralis. Quo ex tempore quinque Dignitates et viginti octo Canonici debent esse insigniti Doctoratus Laurea in Sacra Theologia, aut Licentiatus gradu in jure Canonico, sive in Universitate Complutensi, quam idemmet Card. Ximenius de Cisneros Apostolica, et Regia facultate fundavit, sive in una ex Universitatibus Vallisoletana, Salmanticensi, Bononensi, ac Sorbonensi. Insuper ejusdem Collegialis Personatus, et Ecclesiæ Parochialis Archipresbiter stallum habet in Choro, simul cum Canonicatu potest obtineri; nullatenus vero aliæ Dignitates. Ulterius sunt in præfata Magistrali quindecim Portiones, quæ Magistris in Philosophia debent conferri. Ad hæc omnia inter Regem, Archiepiscopum, et Universitatis Gremium inita fuit Concordia ab anno 1553.

\section{Collegiales Ecclesice Pastrana}

In villa de Pastrana jurisdictionis Ducum del Infantado alia est Collegialis erecta anno 1583, ad Ducum solicitudinem a S.Pontifice S.Pio V. In ea resident octo Dignitates, duodecim Canonici, duodecim Portionarii, decem et sex Cappellani, et quatuordecim Ministri amoviles ad servitium Ecclesiæ. Omnium prædictorum Beneficiorum Collegialis presentatio attinet ad Duces de Pastrana, ut Patronos, et Canonica institutio 
ad Archiepiscopum, præter Decanatum, cuius collatio ad sedem Apostolicam spectat. Visitatio hujus Collegialis Viccario Generali incumbit, et non aliis Visitatoribus, præter Parochialem intra ambitum Collegialis.

\section{Collegiales Ecclesioe Escalona}

In villa de Escalona alia est erecta Bullis Apostolicis Collegialis, in qua resident septem Dignitates, duodecim Canonici, duodecim Portionarii, et totidem Cappellani. Cuius visitatio ad ordinarium spectat, nominatio vero Dignitatum, et aliorum Beneficiorum ad Duces de Escalona, villæ Dominos, et Patronos Collegialis.

\section{Visitatores Districtus Villa de Canales}

Præter Viccarios Generales Toleti, et Compluti commorantes, et Viccarios cum territorio, et jurisdictione territorii ad Diøesesis opportunius regimen jam recensitos, alii etiam Visitatores ab Archiepiscopo eliguntur, qui de aliis territoriis curam visitationis habent. In villa de Canales, in cujus districtu ennumerantur septuaginta quatuor oppi$\mathrm{da}$, et in eis quinquaginta Parochiæ et decem et novem annexæ, quibus omnibus Parochi et Viccarii idonei præficiuntur, ut onus Pastorale, et simul opera pia, et confraternitatum onera adimpleant.

\section{Visitatores Districtus Villa de Zurita}

In districtu villæ de Zurita, in quo comprehenditur villa de Pastrana, alius eligitur ab Archiepiscopo Visitator ut visitet sexaginta quinque oppida, in quibus ennumerantur quinquaginta duo Ecclesiæ Parochiales Matrices et tredecim eisdem annexæ, et etiam confraternitates, quinque Nosocomia, Eremitoria, Congregationes, Montes pietatis, aliaque opera pia quæ omnia accurate adimpleri curat Visitator.

\section{Visitatores Districtus Villa de Ocaña et Guardia}

Ad villas de Ocaña et Guardia eligitur Visitator, qui curam gerat visitandi quadraginta oppida in quibus sunt quadraginta tres Parochiæ Matrices cum quatuor eisdem annexis, et simul Nosocomia, Confraternitates, Montes pietatis, aliaque opera pia.

\section{Visitatores Districtus Villa de Talamanca, Cogolludo et Uzeda}

Ad districtum villarum de Talamanca, Cogolludo et Uzeda alius eligitur ab Archiepiscopo Visitator qui curam gerat visitandi centum viginti tria oppida, in quibus ennumerantur centum viginti novem Parochiæ cum triginta tribus annexis, Cappellanias, Confraternitates, Nosocomia, Montes pietatis aliaque opera pia.

\section{Visitatores Districtus Villae de Rodillas et Montalvan}

Ad districtum villarum de Rodillas et Montalvan alius eligitur ab Archiepiscopo Visitator qui curam gerat visitandi quinquaginta et unum oppida et in eis quinquaginta 
quinque Parochias Matrices cum octo annexis, Cappellanias, Confraternitates, Eremitoria, Montes pietatis et Collegium ed educationem Puerorum.

\section{Visitatores Districtus Villa de Illescas}

Ad districtum villæ de Illescas alius ab Archiepiscopo eligitur Visitator qui curam gerat visitandi viginti oppida, in quibus ennumerantur viginti Parochiæ Matrices, et una annexa, tria Nosocomia, quatuor Xenodochia, Cappellanias, Confraternitates, Eremitoria, aliaque opera pia.

\section{Visitatores Districtus Civitates Complutum et Guadalaxara}

Ad civitates Complutensem et Guadalaxarensem alius eligitur ab Archiepiscopo Visitator qui curam gerat visitandi nonaginta sex oppida, et in eis centum et decem Parochias, plures Confraternitates, aliaque opera pia.

\section{Visitatores Districtus Montes Toletani et villa de Alcocer}

Ad districtum Montium Toletanorum et villæ de Alcocer alius ab Archiepiscopo eligitur Visitator qui curam gerat visitandi triginta oppida et in eis totidem Parochias cum undecim annexis, septem Nosocomia, duas refugii Domos, Confraternitates, Cappellanias, Montes pietatis, aliaque opera pia.

\section{Vigilantia Visitatorum}

Supra ennumeratos Visitatores ita per Diœcesim constitutos invigilat in primis Archiepiscopus, cui intra biennium tenentur reddere rationem omnis suæ visitationis, nisi ante urgeat causa eum admonendi ad quodlibet malum vitandum, aut Clericum coercendum. Præterea coguntur Visitatores integram suæ visitationis rationem ante Consiliarios Gubernationis Archiepiscopatus præsentare; ut ea perspecta, quæ remedio indigent, reparent, et omnia, quæ a S.Tridentina Synodo, vel a Diœcesana sunt præcepta, ad amussim observentur. Nec Præsules Toletani tot coadjutoribus adiuti super gregem sibi comissum vigilare personaliter omittunt: imo per se ipsos quoties aliis maioribus negotiis non sunt præpediti, oppida visitant. Fabricas Ecclesiarum invisunt, Concursui oppositorum ad Beneficia Curata adsistunt, Consilio Gubernationis præsunt, et alia id generis Episcopalia munera explent.

\section{Habitus Parochorum. Libri Parochiales}

In omnibus Parœciis hujus Diœcesis residentiam personalem Parochi habent; fere omnes (præter quosdam Patronatus laici, aut ecclesiastici) eliguntur juxta formam Tridentini prævia, ut superius dixi, affixione edictorum oppositores advocando. Deinde tum in sacra Theologia, vel jure Canonico per horam eorum idoneitatis fit scrutinium, ac demum per dimidium horæ unusquisque in materiis Moralibus examinatur: nec provisi a suis Parochiis discedere valent, nisi prius obtenta licentia, et tempore a Canonibus præscripto. In unaquaque Parochia asservantur libri Baptismi, Confirma- 
tionis, Matrimoniorum et Defunctorum segregatim, et omnia accurate a Parochis scribuntur, juxta Constitutiones Synodales.

Alios etiam libros ad singulares fundationes operum piorum summa diligentia servant; alios ad proventus Fabricarum Ecclesiarum; alios ad Cappellanias earumque bona spectantes; alios ad opera pia Patronatus laicorum; alios denique ad Confraternitates, Nosocomia, Montes pietatis et alia his similia. Qui omnes libri in Archivio custodiuntur, ut tempore visitationis adveniente, cuncta Visitatores perscrutentur, et adimpleri curent.

\section{Verbi Divini pradicatio}

Parochi hujus Diœcesis omnibus diebus festis S.Evangelium stilo plano et simplici exponunt, et fideles sacris Mysteriis fidei imbuunt: Missam pro Populo Deo offerunt omnibus Dominicis, et festis de præcepto, et si pinguioribus reditibus gaudeant, sunt admoniti, ut etiam aliis diebus sacrificium pro Populo applicent.

\section{Tabella piarum fündationum}

In Sacristia uniucuiusque Parochiæ affixa est tabula secundum Constitutionem Urbani VIII et Decreta Synodalia, in qua scripta sunt onera Missarum, Aniversariorum et fundationum piarum, ut certis a testatoribus assignatis diebus adimpleantur.

\section{Fabrica Ecclesiarum}

Ecclesiarum Fabricæ sartæ tectaque manent; vestibus et vasis sacris ad sacramentorum administrationem et functiones ecclesiasticas sunt ornatæ: et si aliqua propter inopiam reparari aut de novo construi indigeat, Visitatores admonent Archiepiscopum, et ejus Consilii judices, ut cito de nova Fabrica, aut de ejus reparatione agatur.

\section{Temporale dominium Prcesulum Toletanorum in quibusdam oppidis}

Hucusque de iis quæ ad regimen spirituale dignoscuntur pertinere. Quoad temporale ad Archiepiscopum spectat dominium Villæ de Talavera et jurisdictio temporalis supra triginta oppida, quæ in ejus districtu computantur. Insuper dominium villæ de Cazorla et earum quæ sub nomine.del Adelantamiento comprehenduntur.

Præterea Complutum, et Villæ de Sn. Torcaz et Villæ-francæ, seu Pontis Archiepiscopi, et Camarena subsunt jurisdictioni Archiepiscopi privilegiis, Regiis donationibus ob præclara et egregia merita, impensas, et alia servitia non parvi momenti, quæ Decessores mei fecerunt a seculo undecimo, in quo Toletum fuit expugnatum et a Maurorum dominatione liberatum usque ad seculum decimum tertium; ita ut veraciter possimus asserere Præsules Toletanos Duces et expugnatores fuisse: quim Archiepiscopus Sanctius Jacobi Aragoniæ Regis filius ipsomet in prœlio adversus Arabes juvenili arreptus ardore immature obiit. Nominat igitur Archiepiscopus in præfatis Villis et oppidis ad temporale dominium suum spectantibus, Prætores et Ministros, qui jurisdictionem exerceant. 


\section{Contentiones inter Dignitatem Archiepiscopalem, et Ordines S.Jacobi de Spata, et Calatravae}

De contentionibus et litibus multis abhinc annis inter Equestres ordinis S.Jacobi et Calatravæ exortis in antecedenti Visitatione B.V. certiorem feci, et juxta S. Congregationis decretum consului de his Exmum. Nuntium hisce in Regnis, ut quando occasio opportuna se se obtulerit, de aliquo remedio provideat.

Militaris Ordo S.Jacobi nominat in villa de Infantes Viccarium, ut in ea, et viginti oppidis jurisdictionem exerceat: alium Viccarium in Villa-Rodrigo, quæ sicut villa de Genabe, et Torres de Albanchez cum Parochiis ad jurisdictionem Ordinis prædicti S.Jacobi pertinet.

In quibusdam oppidis ad Equestres Ordines spectantibus Parochi nominati, post obtentam præsentationem Regis, aut Magni Magistri, seu Administratoris, ante Archiepiscopum, seu ejus Consilium Gubernationis comparent, ut prævio examine ad curam animarum coram Examinatoribus Synodalibus, ab Archiepiscopo titulum approbationis, et collationis obtineant. Sed non idemmet observatur in aliis oppidis præfati Ordinis. Iuxta Concordiam superius memoratam Viccarius et Visitator Militaris Ordinis S.Jacobi in Villa-Rodrigo existens debet non solum titulum Regium impetrare, sed etiam ab Archiepiscopo potestatem obtinere, ut jurisdictionem ecclesiasticam exerceat; sed paucis abhinc annis titulum obtinere recusat, fretus auctoritate Consilii Regis Ordinum Militarium.

Latet me revera hujus inobedientiæ causa, nam si aliis in Diœcesibus robur aliquod valeant habere rationes pro parte Ordinum Militarium, nulla vero adest contra Archiepiscopos Toletanos, quorum ope et auspiciis cœpit Toleti insignis Ordo Equestris de Calatrava; ut ipsimet fatentur in ejus origine a S.Raymundo de Fitero, et Didaco Velazquez, Monachis Cisterciensibus, qui a Joanne Archiepiscopo Toletano adjuti primum iter adversus Calatravam inierunt. Necnon Ordinem Equestrem S.Jacobi quanto favore prosequuti fuerint apud Hispaniarum Reges Præsules Toletani, quantisque auxiliis iuverint, ut protenderetur, testes sint Archiepiscopi Ximenius et Petrus de Luna Patrui, et Joannes de Zerezuela frater uterinus illius Magni Magistri Alvari de Luna, qui tanto se suumque Ordinem extulit, ut magno casu ruerit, causamque Regibus Catholicis dederit, ut a Sede Apostolica impetraverint facultatem suspendendi electionem Magnorum Magistrorum, et hanc Dignitatem et administrationem bonorum Militarium Ordinum incorporandi Regiæ Coronæ.

In disctrictu Ordinis Militaris de Calatrava ennumerantur 26 oppida, et totidem Parochiæ, quæ ad jurisdictionem ordinariam spectant; licet id diffiteantur ejus Religiosi in contentionibus exortis, quæ nullatenus possunt sopiri in cœtu, quem vocant, Apostolico: raro etenim judices congregantur ad decidendum ex bono et æquo: maiorque eorum numerus est Equitum Ordinum Militarium. Quapropter si prædictus cœtus Regio assensu extingueretur, et omnium causarum cognitio ad Tribunal Nuntii Apostolici hisce in Regnis, quod hodiedum Rotæ Hispaniensis vocatur, rediret, cuncta ad suum statum et ecclesiasticæ disciplinæ observantiam absque ulla imminutione privilegiorum Ordinum Equestrium revocarentur. 
Hæc omnia, B. Pater, sincero animo, maximaque reverentia hucusque exposui, ut tanquam obediens patri filius, quæ mei muneris sunt, a Sede Apostolica addiscam; superiorique lumine omnium Ecclesiarum Magistræ illustratus, maiori fervore, maturiori consilio, et faciliori succesu, quæ meo muneri desunt, partes, expleam: et B.V. ad me conversa roboret, confirmet, et benedictionem Apostolicam benigne impartiatur: Deusque O.M. Beatitudinem Vestram ad bonum Ecclesiæ regimen diu sorpitem, atque incolumem servet. Toleti, die XX Martii anni Domini MDCCLXXX.

(Firma autógrafa del arzobispo)

Beatissime Pater

Ad B.V. pedes humillime provolutus

Fran $^{\text {cus }}$. Archpus. Toletanus

5.3. Informe ${ }^{13}$ del arzobispo don Francisco Antonio Lorenzana. Año 1784

Beatissime Pater

(Saludo. Se excusa de no ir personalmente)

Certiorem jam feci B.V. de statu sanctæ meæ Ecclessiæ Toletanæ per transmissas a me superioribus annis relationes: tantummodo superest, ut rursus obedientiam meam erga Sedem Apostolicam ostendam, reverentia exorans ut mihi benigne dignetur indulgere facultatem ad visitanda per Procuratorem Apostolorum limina; tanto etenim terrarum spatio disjungor, ut personaliter visitare nequeam loca illa in quibus exuriæ SS. Apostolorum reconduntur, mira nostræ Religionis exordia memorantur, errorum nebulæ discutiuntur, et in quibus Cathedra Petri magistra veritatis omnes edocens gentes, firma et stabilis perseverat.

(Reforma en el Colegio de Infantes. Intento de acuerdo con las Ordenes Militares. Ajustes con la Rota Romana. El Consejo Real).

Cum Ecclessiæ meæ Capitulo sedulo agere curo ut Collegium quod vocant Infantium ad formam Tridentini, ut mihi a Sacra Congregatione injunctum, revocem; necnon lites sopire cum ordinibus equestribus S. Jacobi de Spata, Calatravæ et S. Joannis Jerosolimitani totis viribus contendo; et ut id facilius assequi valeam, de consilio Excmi. Dni. Nuntii hisce in partibus ad tribunal suum Rotæ Hispanicæ nuncupatum restitui cognitionem quæ ad Congregationem auctoritate Apostolica erectam hodie spectat, summopere desidero; in præfata enim Congregatione Senatorum Regis a Consilio nec dirimendi negotia, nec discordis finiendi spes afulget.

13 ASV, Congregación del Concilio, Relationes Dioecesium, Toletana 805-B. 


\section{(Exposición del SS. Sacramento: problemas con los religiosos)}

A meo decesore Cardinali Cordoba sæpius fuit cautum edicto, ut expositiones SSmi. Eucharistiæ Sacramenti non levi ex causa et cum debita Ordinarii licentia fieretur; sed huic mandato quidam absistere Regulares suis innixi previlegiis. Verum cum hac in re a potestate Episcopi non sint substracti, et aliunde, sim paratus eis facultatem ad expositionem faciendam certis diebus ex solemnitatibus juxta Apostolica decreta, impartiendi; enixe et humillime exoro B.V. ut tam salubri mandato jubeat obedire Regulares qui legi Diœcesanæ et omnibus quæ ad fidelium cultum attinet, obtemperare tenentur.

\section{(Religiosos: que se les mande obedecer)}

Sint licet Ordinarii potestate soluti, exhibere nullatenus cogantur expensarum suarum rationesq. agnoscant suos superiores in Monastica disciplina, revereantur tamen Episcopum Diœcesanum suum Pastorem qui illos ad sacros ordines provehit et licentiam ad sacramenta pœnitentiæ administranda et prædicationem Verbi Dei concedit: et tandem uniformitatem in cultu cum clero servent. Experimento enim Matriti compertum est conditiones a bonæ memoriæ Urbano VIII in expositione SSmi. præscriptas nullo modo ab eis servari: ita ut nec expositio fiat in altari majori, nec imagines cooperiantur, nec psalmi seu cantica spiritualia alternatim personent, nec vigiles ad minus duo ante SSmum. adsistant; sed passim fieri expositionem decernunt quolibet in altari cum luminaribus, sed sine secerdotum assidua custodia; passim discoperinut et operiunt ad instantiam privatarum personarum, et non publica ex causa.

\section{(Despedida)}

Accedo igitur ad B.V. ut ea ipsa quæ sacris constitutionibus sunt stabilita, sarta tecta maneant. Et interea D.O.M. deprecor et B.V. diu sospitem et incolumem bono universalis Ecclessiæ servet. Toleti die 5 februarii anni Dni. 1784.

(Firma autógrafa del Arzobispo)

Beatissime Pater

ad B.V. pedes humillime provolutus

Fran. ${ }^{\text {cus }}$ Archpus. Toletanus

5.4. Informe ${ }^{14}$ del arzobispo don Francisco Antonio Lorenzana. Año 1788

Beatissime Pater.

(Relato del vije y visita pastoral a Orán, y a los pueblos del camino de Toledo a Cartagena, y de Cartagena a Toledo, vía Huescar, Cazorla, Almagro y Ciudad Real).

14 ASV, Congregación del Concilio, Relationes Dioecesium, Toletana 805-B. 
Cum illud, Beatissime Pater, in munere Pastorali sit præcipuum, oves proprias verbo et exemplo pascere, easque frequenter conspectu recreare ac fovere; ex quo mihi, licet immerito, id oneris Dei providentia et Apostolicæ Sedis gratia injunctum est, universum fere Archiepiscopatum lustrare curavi, optans interea ut Ecclesiæ Oranensis quæ in ora Africana sita magno terræ marisque intervallo a Toletana sede disjuncta est, aliquando invisendæ occasio daretur opportuna: cujus voti quandoquidem compotes facti sumus, de confecto itinere, deque ejus fausto sucessu justum nobis visum est ad B.V. Pastorem summu referre; nam de Ecclesiæ meæ statu superioribus jam annis Apostolicis obsequens decretis B.V. certiorem fecimus.

Equidem bellum cum antea perpetuum a nobis cum Africanis gereretur, maria erant prædonum incursibus adeo infesta, res ut esset periculi plena ejusmodi navigatio; quare factum est ut ab ea ineunda non semel deterriti simus, ne per imprudentiam Archiepiscopalis Dignitas Barbarorum ludibrio committeretur: nunc vero induciis cum Africano Dynasta jam factis, periculi timore magna ex parte sublato, iter incunctanter arripere decrevimus; ac primum vota nostra consiliumque Catholico Regi exposuimus, qui quidem pro ea qua nos benignitate ac benevolentia prosequitur, nobis renunciari mandavit hujusmodi consilium sibi valde probari, atque ad illud commodius, tutiusque perficiendum navim Regiam suo jussu in Carthaginensi portu paratam fore.

Igitur alacres et impigri ad XVII Kalendas Maias sub vesperam anno 1786 iter aggressi sumus Toleto recta Carthaginem contendentes, ea tamen ratione ut dum intra hujus Diœceseos fines versati sumus, paulo lentius progrederemur nullo in transitu oppido prætermisso; quin clerum populumque Pastorali admonitione ad virtutem officiumque excitaverimus. Tandem post decem dies Murciam urbem Carthaginensis Episcopi sedem pervenimus, a quo fraterne ac humanissime excepti, atque trium dierum mora recreati, Carthagine eo comitante deducti sumus. In portu constituti, cum contra nitentibus ventis solvere non liceret per dies duodecim expectare opus nobis fuit interea tamen mutua officia charissimo Coepiscopo suffraganeo nostro rependere studuimus, quodque ille pro infirma qua utebatur valetudine omnino præstare non valebat, in nos lubenter suscepimus, et continuis diebus magnæ fidelium multitudini Confirmationis sacramentum ministravimus, nonnullasque pro re nata ad populum conciones habuimus.

Hæc inter navigandi tempestas paulo quam antea opportunior data est: itaque longioris moræ pertæsi navim conscendimus jam ante paratam atque $a b$ omni re optime instructam. E portu solvimus die undecima Maii, atque ante horas triginta ad Africanam oram secundis ventis devecti, Oranensem portum appulimus; omnium ordinum concursu, plausuque excepti, ut facile in ore omnium vultuque appareret quanta ipsos ex proprii Pastoris adventu lætitia affecerit, quem a tempore Cardinalis Ximenii de Cisneros illius præsidii inclyti expugnatoris desiderabant, licet dignissimi decessores mei Episcopis Auxiliaribus hanc curam demandaverint; ne quid videlicet christiana illa republica detrimenti caperet. Quamdiu ibi commorati sumus id unum curavimus, nullum ut Pastoris officium in nobis desideraretur. Solemnem Ecclesiæ visitationem peregimus, in vitam moresque omnium Ecclesiæ ministrorum sedulo ac prudenter inquisivimus, Vicariumque simul nostrum de universa illius Ecclesiæ administrandæ ratione opportune admonuimus. Ordinationes habuimus, et quos doctrina moribusque 
probatos juvenes reperimus, clericis adnumeravimus; cumque anniversarius dies per illud tempus recurreret, quo sæculo XVI sub regibus catholicis Ferdinando et Elisabetha e Maurorum manibus a nostris civitas illa recuperata fuit, ritu solemni eo die Missæ sacrificium in gratiarum actionnem celebravimus, clero, militiæ duce, populoque adstantibus. Pauperibus ægrotantibus publicis in Nosocomiis, in carceribus detentis, orphanisque subvenimus; quin et maxime omnium ærumnosum hominum genus qui ob atrocia flagitia ad graviora exercitia damnati sunt, præcipua miseratione prosecuti sumus, atque omnibus quibus potuimus subsidiis sublevavimus; neque solum per nosmetipsos ad pœnitentiam adhortati sumus, sed per idoneos commendabilesque viros quos nobis comites adjunximus, quique illis diebus in edocendo e suggestu populo excipiendisque peccatorum confessionibus alacriter strenueque laborarunt.

Omnibus itaque rebus confectis, revertendi consilium maturius aliquanto quam constitueramus, suscipere nobis opus fuit, ne occasione opportuna ut navarchio videbatur, elapsa, deinceps perturbato mari redditu prohiberemur. Orano igitur vela dedimus die vigesima secunda Maii, non tam facili ac antea navigatione, siquidem aliquanto jactati ac nauseabundi non nisi post duos dies cum dimidio Carthaginensem portum tenuimus. Atque in ea urbe tantum constitimus quantum recreando e superiori jactatione corpori per diem unum opus fuit, et commeatui necessario curando.

Redditum vero nostrum ita disposuimus, ut magnam Archiepiscopatus partem nondum a nobis antea lustratam circumierimus, ad meridionalem plagam qua Almeriensi et Giennensi Diœcesibus confinis est. Quo in itinere duos fere menses consumpsimus, multis viarum incommodis quæ magnas partes angustæ, prærruptæ ac nullis fere vestigiis frequentatæ sunt, alacriter superatis: ovium enim amor ac desiderium quo ducebamur, animum et corpus simul exigebat. Oscam igitur (Huescar) quatuor dierum itinere pervenimus, ibique totidem dies in fidelibus confirmandis, populoque erudiendo transegimus. Ecclesias visitavimus, eisque de omnibus rebus ad spiritualem animarum proventum spectantibus abunde providimus. Cum enim multos in ea regione ad commodiorem agrorum culturam vel sparsim per agros in propriis villis vel in pagis valde ub urbe dissitis degere intellexerimus, qua ex re ad Ecclesiam Parochialem raro per annum convenire poterant, Presbyteros doctrina et virtute probatos opportunis locis præficimus, qui et illis erudiendis e proximo invigilent; atque ad sacramenta conferenda prompti sint ac parati.

Osca Cazorlam petivimus, ita per oppida obvia discurrentes ut in singulis præter conciones ad populum, confirmationisque administrationem, Ecclesiarum quoque visitationem perfecerimus. In Cazorla vero civitate quæ Prædecessorum nostrorum præcipue Ruderici Ximenii de Rada ope et virtute e Maurorum potestate superioribus sæculis erepta, Catholicorum Regum beneficio nostræ ditioni subjecta est cum aliis eidem adnexis oppidis, majorem dierum numerum consumpsimus in Ecclesia visitanda, erudiendis confirmandisque fidelibus, et minoribus ordinum gradibus conferendis. Inde ergo medio mense Junio discessimus, atque per Almagrum ac Civitatem Regiam (Ciudad Real) Toletum incolumes regressi sumus, tribus fere mensibus toto in hoc itinere consumptis. Quæ omnia B.V. quam gratissima fore facile speramus, cui nihil antiquius est quam ut a singulis Ecclesiarum Pastoribus Apostolici ministerii partes expleantur. 
Deum igitur optimum maximum deprecor ut B.V. diu sospitem incolumemque bono Ecclesiæ servet.

(Escrito por otra mano)

Toleti die XXX Januarii anni Domini MDCCLXXXVIII.

\author{
(Firma autógrafa del arzobispo) \\ Beatissime Pater \\ Ad B.V. pedes humillime provolutus
}

Fran. ${ }^{\text {cus }}$ Archpus. Toletanus

\title{
5.5. Informe ${ }^{15}$ del arzobispo don Francisco Antonio Lorenzana. Año 1792
}

\section{Beatissime Pater}

Utinam nullæ prorsus difficultates prohiberent quominus ad Sanctorum Apostolorum limina per meipsum visitanda sanctissimas et dulcissimas eorum exuvias venerandas S.V. presentem intuendam pedes humillime, uti par est exosculandos, ac totius Toletanæ Archi-Diøceseos rationem con(..) reddendam liceret pergere. Nihil profecto jucundius, nihil honorificentius, ut qua decet ingenuitate loquar, mihi, qui animo devotissimo atque obsequentissimo erga V.B. verum Jesu-Christi Vicarium, verumque Petri Successorem, semper ero, posset contingere; sed cum gravissimmæ causæ, longissimum iter, imprimisque diuturna ab Archiepiscopatu absentia meme volenti et ardenter desideranti animo indulgere non patiantur, ad $\mathrm{V}^{\mathfrak{x}}$. $\mathrm{B}^{\mathrm{s}}$. omnibus perspectissimam clementiam mea tenuitas audet recurrere humillitate maxima deprecans, ut mihi vellit concedere Sancta Apostolorum limina per idoneum delegatum adire, et V.B. de meæ Archi-Diœceseos Toletanæ statu per præsentes litteras certiorem facere.

\section{(Cumplimiento de sus deberes como pastor)}

Curavi equidem superioribus annis id absolvere tam mei muneris memor quam Prædecessorum meorum quibus nihil antiquius quam erga Romanam Sedem subjectio et obedientia laudabili exemplo perductus: Numquam destiti ex quo ad hujus Archiepiscopatus regimen, licet immerito evectus fui hortari et admonere Parochos ut secum meditantes ipsam Æterni Patris Sapientiam in terras descendisse, quo in carnis nostræ humillitate cœlestis vitæ præcepta nobis traderet, fiant parvuli in medio fratrum suorum docentes eos stilo plano et aperto Sacro-sanctæ nostræ Religionis misteria, instruentes etiam præceptis earum rerum quas ad vitam et mores componendos necessarias arbitrentur, præbentes singulis alimenta sanæ et incorruptæ doctrinæ, fugientes novitates et peregrinas assertiones, quibus impietas solet simplicium Christianorum animos depravare.

15 ASV, Congregación del Concilio, Relationes Dioecesium, Toletana 805-C.

Instituciones eclesiásticas Hispania Sacra 54 (2002) 


\section{(Construcción de un Albergue para pobres en Ciudad Real)}

Nihil prætermitto quod meorum populorum spiritualia et temporalia bona augere posse intelligo: Erexi his postremis annis meis sumptibus publicam Charitatis domum in Civitate Regia (hispano sermone Ciudad Real, quæ urbs totius Marchiæ Laminitanæ caput est) ubi ingens pauperum numerus alitur, multa ad vestitum necessaria texuntur, edocenturque plurimi artes, quibus non multo post tempore et sibi et Patriæ charos exaturos fore confido.

\section{(Visita pastoral. Cumplimiento de los decretos)}

Anno proxime elapso cupiens observare diligentissime Summorum Pontificum iteratas Constitutiones necnon Tridentinæ Synodi prudentissima Decreta visitationem hujus meæ Toletanæ Ecclesiæ iam inde a plurimis annis non factam, exorsus fui, eam omni studio ad finem perducendam curo, quidquid ad divinum cultum promovendum conducere video, facio, extirpoque quiquid eum inminuere, Ecclesiæque decorem obscurare posse videtur.

\section{(Nuevo Hospital para dementes en Toledo)}

Duobus abhinc annis lamentabilem dementium sortem miseratus ingens hospitium eorum commodo exædificare cœpi, in eo extruendo maximus Artificum et pauperum numerus est, necessarios sumptus suggero, omnem diligentiam adhibeo ut maiori qua possit celeritate properetur, brevique spero consumandum: Erat quidem antea in hac urbe domus dementia laborantibus destinata sub mei Capituli administratione; sed quæ ob exiguitatem, situm, et celullarum tetras angustias majorem et acerbiorem morbum redderet; contra vero quam nunc ædifico, ampla est, in salubriori urbis loco posita, luci et vento pervia, exhilarando animo peraccommoda, vicinus ei campus amœnissimus, balneario proxima, omnibusque bonis prædita, quæ menti recuperandæ consentanea existimantur: Neque enim Beatissime Pater, Ecclesiæ meæ Thesauros usquam melius collocari posse puto, quam cum in sacris Ædibus tuendis et ædificandis, Nosocomiis erigendis, egenorum et pauperum miseriis sublevandis impenduntur idque etiam V.B. exemplo edoctus, cujus animum certo scio nunquam esse nisi de Deo et felicitate publica cogitantem.

\section{(Exhortación al clero. No hay errores ni herejías)}

Denique, Beatissime Pater, nunquam desino excitare, accendere, inflammare et omnibus modis impellere Vicarios, Judices, Parochos, Nobiles prædivites, cæterosque fideles mihi concreditos ad sua munera exacte obeunda: et quidem summo cum gaudio $\mathrm{V}^{\mathfrak{x}}$. $\mathrm{B}^{\mathrm{ni}}$. asseverare possum in mea Archidiœcesi Sacrosancti Concilii Tridentini Decreta adamussim servari, nullum adversus Catholicam Fidem errorem reperiri; sed potius omnes puram et illibatam religiosissime conservare, Vestramque Beatitudinem tanquam suum supremum Caput et communem Parentem jucundissime exaudire et revereri. 


\title{
(Despedida)
}

Exposui, Beatissime Pater, $\mathrm{V}^{\mathfrak{x}}$. $\mathrm{B}^{\mathrm{ni}}$. omnium rerum hujus Toletanæ Ecclesiæ presentem statum, laboresque et publica Opera pro communi Populorum bono suscepta, in quibus si quid emmendatione dignum reperiatur, spero $\mathrm{V}^{\mathrm{m}}$. $\mathrm{B}^{\mathrm{m}}$. clementer admonituram, nam quod ad me attinet polliceor sua præcepta promptissimo, uti justum est, animo semper exequi.

Interea ad D.O.M. supplices preces fundo $\mathrm{ut}^{\mathrm{m}}$. $\mathrm{B}^{\mathrm{m}}$. maximo Ecclesiæ bono et omnium Fidelium solatio diu sospitem et incolumemque servet.

Datum Toleti die XX Januarii ann. MDCCXCII.

(Firma autógrafa del cardenal)

Beatissime Pater

Ad B.V. pedes humillime provolutus

Franciscus Cardinalis Archpus. Toletanus

5.6. Informe ${ }^{16} \mathrm{del}$ arzobispo don Francisco Antonio Lorenzana. Año 1796

\author{
Beatissime Pater \\ (Se ha completado la Visita Pastoral)
}

$\mathrm{Ab}$ anno millesimo septingentesimo nonagesimo secundo, quo majori qua decet reverentia, et erga Sedem Apostolicam obedientia, Beatitudini vestræ Ecclesiæ meæ et muneris Pastoralis rationem reddidi, simulque per procuratorum limina Sanctorum Apostolorum Petri, et Pauli visitavi, quatuor annis transactis, per memetipsum adhibito Socio Reverendo Episcopo Caristensi Auxiliari meo, ad districtum Vicariæ Sancti Joannis hujus Diœcesis accesi, locaque illius quamplura perlustravi in eisque Sacaramentum Confirmationes ministravi, cæteraque munia Episcopalia peregi: inde ad territorium Vicariæ de Alcaraz eiusdem meæ Diœcesis, in eaque officium Pastorale adimplere conatus sum. Postea invitatus a Perillustri Domino Priore Conventus de Uclés Regii Ordinis Sancti Jacobi una-cum prædicto Episcopo Auxiliari meo, in Oppidis, quæ illius jurisdictioni subsunt, Sacramentum Confirmations contuli omnibus fidelibus qui gratiam Spiritus Sancti nondum receperant.

\section{(Se ha terminado la construcción del Hospital de dementes)}

Ad hæc, silentium præterire non debeo, me perfecisse Toleti Domum Hospitalis Dementium, cuius administratio ad Capitulum Toletanum pertinet, et propter arctitudinem pervetustæ Domus, recipi non poterat nisi exiguus numerus infirmorum, ad præsens autem inhabitant amplum ædificium balneis, separationibus, et exseliis, ut ad meliorem frugem redeant, optime instructum.

16 ASV, Congregación del Concilio, Relationes Dioecesium, Toletana 805-C.

Instituciones eclesiásticas Hispania Sacra 54 (2002) 


\section{(Intenta dar a conocer la condena al Sínodo de Pistoia)}

Non solum ut Episcopus, Beatissime Pater, sed ut Inquisitor Generalis, non tantum jurisdictione ordinaria, sed præcipue Auctoritate Apostolica mihi a B.V. collata fretus, insistere non desino ut Bulla Dogmatica a B.V. expedita in qua Synodus Pistoyensis damnata est, quantotius omnibus fidelibus nota fiat; meoque ardenti desiderio accedit Excellentissimus Dominus Nuncius Apostolicus hocce in Regno, votisque nostris speramus in Domino Auctoritatem et Religionem Regis mei Catholici non defuturam.

\section{(Lamento por la persecución religiosa en Francia)}

Agnosco, Beatissime Pater, iis difficillimis temporibus Ecclesiæ navim fluctibus adversariorum nimis jactari: fateor viris Præsulum Catholicorum defessas ad detegendas inimicorum insidias fere non sufficere: video Præsules Ecclesiæ Gallicanæ exsules, extorres, omni facultate orbatos, suaque in Patria clam residentes, aqua et igne esse interdictos, et expulsos hinc inde emigrare sine pera, sine baculo, et sine calceamentis, ita ut Priorum Ecclesiæ Ministrórum persecutiones in memoriam revocentur, et ad exemplum Divi Pauli Apostoli in speluncis, et in cavernis alii ob metum abscondantur, alii in profundo maris jaceant, et ærumnas calamitatesque vitæ assiduo patiantur. jOh bone et piissime Deus, qui nos tanquam aurum in fornace probas, et igne adversariorum purificas!

\section{(Ayuda que se presta al clero francés refugiado)}

Prout suppetunt facultates huius Archiepsicopatus, non solum benigne recipere Episcopos, et Presbyteros Gallos omni studio ab initio persecutionis curavi, sed etiam in Monasteriis, et piis Domibus locare, confovere, solari, et eorum necessitatibus subvenire non desisto, per memetipsum, per confratres Hispaniarum Episcopos, per Sacrorum Religiosorum Ordinum Prælatos, per Cathedralium Canonicos, et Parochos, et Missarum eleemosinis adjuvare contendo. Faxit Deus ut cuncta prospere eveniant, ut vera Ecclesiæ pax post tempestatem quantotius redeat, et lumen fidei orthodoxæ in mentibus Gallorum elucescat! Errorum tenebræ dispareant, et omnes uno ore Dominum Nostrum Jesum Christum fateantur, et Misteria legis Evangelicæ agnoscant! Beatitudinemque Vestram ad omnium solamen ad extirpandas Hæreses, et Ecclesiæ gubernaculum diu sospitem incolumemque servet. Interea vero B.V. pedes humillime deosculor. Matriti die decima quarta mensis Februarii anni millesimi septingentesimi nonagesimi sexti.

(Con letra de otra mano y firma autógrafa del cardenal)

\section{Beatissime Pater}

Ad Beatitudinis Vestræ

pedes humillime provolutus

Franciscus Cardinalis de Lorenzana 


\section{INDICE GENERAL DEL TOMO LIV}

Págs.

\section{- EPISCOPADO HISPANO}

JoRGE LÓPEZ QUIROGA, Actividad Monástica y acción política en Fructuoso de Braga

ILUMINADo SANZ SANCHO, Episcopologio medieval cordobés. Siglos XIIIXIV

CARLOS M. LÓPEZ-BREA, Conflictos de jurisdicción eclesiástica en la España de finales del Antiguo Regímen: los límites del episcopalismo borbónico

$69-84$

- ÓRDENES RELIGIOSAS

Artemio Manuel Martínez Tejera, Cenobios leoneses altomedievales ante la europeización: San Pedro y San Pablo de Montes, Santiago y San Martín de Peñalba y San Miguel de Escalada

EVA María ST. Clair SEgURAdo, La cuestión de los ritos chinos y malabares: desobediencia e idolatría en la compañía de Jesús

EduARdo JAVIER Alonso Romo, De Castilla al Oriente Portugués: cuatro medinenses y sus escritos luso-castellanos

INMACULADA FERNÁNDEZ ARRILlAGA, Los novicios de la compañía de Jesús: La disyuntiva ante el autoexilio y su estancia en Italia

- IGLESIA EN GALICIA

Mercedes VÁzQuez Bertomeu, Obispos in partibus infidelium en la archidiócesis compostelana (1405-1524)

JosÉ ANTONIO VÁZQUEZ VILANOVA, Los estudios en los seminarios españoles del siglo XIX. El ejemplo de la diócesis compostelana

Eutimio Sastre Santos, Una exposición del Arzobispo de Santiago de Compostela, José, Cardenal Martín de Herrera, origen de la Conditae a Christo, 8 diciembre 1990

- AMÉRICA

Misael Camus IbaCaChe, La iglesia chilena a fines del siglo XIX: un paradigma pastoral

RAFAEL SÁNCHEZ Y CONCHA BARRIOS, Los santos y las concepciones políticas y sociales en el Perú virreinal

ALFONSO ESPONERA CERDÁN, Las «noticias de la provincia de Californias» (1794), de Luis Sales 
Págs.

\section{- RESEÑAS}

BRUNET, Serge: Les prêtres des montagnes. La vie, la mort, la foz dans les Pyrénées centrales sous l'Ancien Régime, por $\mathrm{M}^{\mathrm{a}}$ Luisa Candau Chacón. ...

Del VAlLe RodrígueZ, Carlos: La inconsistencia de los dogmas cristianos, de Crescas. Bittul 'iqqare ha-Nosrim, por José María Soto Rábanos .

CUENCA TORIBIO, José Manuel: Sindicatos y partidos católicos españoles: ¿Fracaso o frustración? 1870-1977, por Manuel Revuelta González

PRETO, Livro: Cartulário da Sé de Coimbra. Edição Crítica, por José María Soto Rábanos

SABE ANDREU, Ana María: Las cofradias de Avila en la Edad Moderna, por Esteban Mira Caballos

Palacios Martin, Bonifacio (Dir.): Colección Diplomática Medieval de la Orden de Alcántara (1157?-1494), por Iluminado Sanz

REINHARDT, Elisabeth (dir.): Tempus implendi promissa, Homenaje al Prof. Dr. Domingo Ramos-Lissón, por Antón M. Pazos

VÁzquez García-Peñuela, José María: El intento concordatario de la segunda República, Antón M. Pazos

VILAR, Juan B.: El Cardenal Luis Belluga, por Luis Álvarez Gutiérrez

ANDRÉS-GALLEGO, José: Literatura sobre los fundamentos: nota crítica

$395-406$

- RELIGIÓN, ETNIA Y NACIÓN

LUIS A. GARCíA MORENO, Etnia goda e iglesia hispana

$415-442$

JESÚS MARÍA GARCía AÑovERos, Iglesia e Indigenismo

$443-472$

JosÉ MANUEL CUENCA TORIBIO, Algunas notas sobre el nacionalismo español (1812-1936)

$473-484$

$M^{a}$ Pilar SALOMÓN CHÉliz, El discurso anticlerical en la construcción de una identidad nacional ėspañola republicana (1898-1936)

$485-498$

- RELACIONES INTERRELIGIOSAS

DAVID J. WASSERSTEIN, The christians Al-Andalus: same awkward thoughts ....

EMILIO MITRE FERNÁNDEZ, Otras religiones ¿otras herejías? (los judíos en el medievo europeo y el especial caso hispánico)

$501-514$

$515-552$

- INSTITUCIONES ECLESIÁSTICAS

Francisco JAVIER RoJo AliQue, El proceso de fundación del convento de San Francisco de Valladolid (H. 1220-1275) 
Págs.

ILUMINADO SANZ SANCHO, Los obispos del siglo XV

$605-678$

David Gonzalo Millán y Fernando del Ser PÉrez, Las relaciones de visitas «ad limina» de los obispos de Osma en los siglos XVI-XVII

$679-736$

ÁNGEL FERNÁNDEZ COLLADO, Los informes de visita ad limina del cardenal Lorenzana en Toledo (1772-1800)

$737-800$ 